Georgia State University

ScholarWorks @ Georgia State University

3-2-2008

\title{
Complementarity and Custom in Wage Contract Violation
}

John Sabirianova Earle

Central European University, earle@gmu.edu

Klara Sabirianova Peter

Georgia State University, kpeter@unc.edu

Follow this and additional works at: https://scholarworks.gsu.edu/uwrg_workingpapers

\section{Recommended Citation}

Earle, John Sabirianova and Peter, Klara Sabirianova, "Complementarity and Custom in Wage Contract Violation" (2008). UWRG Working Papers. 13.

https://scholarworks.gsu.edu/uwrg_workingpapers/13

This Article is brought to you for free and open access by the Usery Workplace Research Group at ScholarWorks @ Georgia State University. It has been accepted for inclusion in UWRG Working Papers by an authorized administrator of ScholarWorks @ Georgia State University. For more information, please contact scholarworks@gsu.edu. 
Working Paper 2008-3-2

Marach 2008

\title{
Complementarity and Custom in Wage Contract Violation
}

\author{
John S. Earle
}

Central European University

Klara Sabirianova Peter Georgia State University 


\title{
COMPLEMENTARITY AND CUSTOM IN WAGE CONTRACT VIOLATION*
}

\author{
John S. Earle \\ Upjohn Institute for Employment Research \\ Central European University
}

and

Klara Sabirianova Peter

Georgia State University

CEPR and IZA

\begin{abstract}
We analyze a model of wage payment practices in which strategic complementarities arise because each employer's costs of delaying wages decrease with the arrears in its labor market. The model is estimated on panel data for workers and firms in Russia, facilitating identification through fixed effects for employees, employers, and local labor markets, and instrumental variables based on policy interventions. The estimated reaction function displays strongly positive neighborhood effects, and the estimated feedback loops - worker quits, effort, strikes, and legal penalties - imply that costs of wage delays are attenuated by neighborhood arrears. We also study a nonlinear case with two stable equilibria: a punctual payment and a late payment equilibrium. The estimates imply that the theoretical conditions for multiple equilibria under symmetric labor market competition are satisfied in our data.
\end{abstract}

JEL Classifications: A12, B52, J30, K42, L14, O17, P31, P37

Keywords: contract violation, wage arrears, social custom, strategic complementarity, neighborhood effect, social interactions, multiple equilibria, network externality, transition, Russia

*Earle: 300 S. Westnedge Ave., Kalamazoo, MI, 49007 (earle@upjohn.org). Sabirianova Peter: 682 Amsterdam Ave. NE, Atlanta, GA, 30306 (kpeter@gsu.edu). This paper is a shortened version of our working paper (Earle and Sabirianova Peter, 2006), which contains more extensive discussion and citations on several issues. Our early research on the topic was supported by the European Union's Tacis ACE Programme, Ford Foundation, and MacArthur Foundation. We thank Paul Milgrom for a conversation that encouraged us to develop the formal model. We are also grateful to Masahiko Aoki, Andrzej Baniak, David Brown, Jiahua Che, Fabrizio Coricelli, Steven Durlauf, Tore Ellingsen, Bob Flanagan, Guido Friebel, John Garen, Scott Gehlbach, Vladimir Gimpelson, Yuriy Gorodnichenko, Ben Jones, Rostislav Kapeliushnikov, Hartmut Lehmann, Larry Levin, Joanne Lowery, Peter Murrell, Ugo Pagano, Mark Schaffer, Andrew Spicer, Bill Sundstrom, Almos Telegdy, Valery Yakubovich, Yuriy Yegorov, two anonymous referees, and participants in conferences and seminars in Atlanta, Berkeley, Bonn, Boston, Budapest, Edinburgh, Kalamazoo, Madison, Maryland, Moscow, Prague, Seattle, and Stanford for helpful comments and discussions, but reserve to ourselves the responsibility for any errors. 
"You shall not withhold the wages of poor and needy laborers, whether other Israelites or aliens who reside in your land in one of your towns. You shall pay them their wages daily before sunset, because they are poor and their livelihood depends on them; otherwise they might cry to the Lord against you, and you would incur guilt.”

Deuteronomy 24: 14-15

\section{Introduction}

The wage contract is a fundamental economic institution whose essential elements are agreements concerning the nature of the work, the wage to be paid, and the schedule of payment. Economists typically assume that employers abide by their side of the contract, paying their employees reliably and on time, which appears to conform with normal practice in developed market economies. ${ }^{1}$ But the assumption is not always warranted, as evidenced by Moses' ancient injunction to the Israelites, and it is clearly violated in post-Soviet Russia, where failures to pay wages on time have been substantial and persistent. At the peak of wage arrears in late 1998, 62 percent of Russian workers reported overdue wages averaging 4.8 monthly salaries per affected worker, with rates much higher in some areas and much lower in others. ${ }^{2}$

Why do most employers regularly honor their wage contracts, but in some cases breach them on a large scale? These extreme outcomes are difficult to explain by any single, continuously varying factor such as the effectiveness of legal enforcement. The legal system is presumably part of the answer, but as Horace put it in 23 B.C., "Of what use are laws empty of customs?”3 In this paper, we argue that the practices of honoring or breaching wage contracts are characterized by increasing returns resulting from interactions within local labor markets. Among firms, strategic complementarities arise because an employer's costs of violating its contracts decrease in the extent to which competing employers violate their contracts. Among workers, social interactions and outside opportunities affect responses to nonpayment, with the responsiveness decreasing in the pervasiveness of contract violations in the local area. In particular, workers are less likely to quit, strike, or shirk in response to their own arrears if violations are common in their reference

\footnotetext{
${ }^{1}$ In fact, there is no systematic data collection about breaches of the wage contract in most economies (perhaps because they are rare), although anecdotal evidence suggests they do occur. The total number of wage and hour rule violations in the US during fiscal year 2003 (including some failures to pay wages on time) is reported by Department of Labor (2003), with 31,123 complaints involving 342,358 employees and \$213mln in back pay.

${ }^{2}$ We discuss definitions and data sources in the next section. Substantial wage arrears were characteristic of the Soviet economy in the 1930s (Gregory and Tikhonov, 2000), and they have also appeared in some other formerly socialist economies (Croatia, Kazakhstan, Moldova, Ukraine), but not elsewhere in Eastern Europe and former Soviet Union.

3 “Quid leges sine moribus vanae proficiunt” (Odes, 3.24).
} 
group. Furthermore, the legal system itself is endogenous because the effectiveness of contract enforcement within a jurisdiction is negatively related to the prevalence of violations as a result of congestion externalities and changing norms among workers and enforcement agents such as judges and prosecutors. These quit, strike, effort, and legal responses are feedback mechanisms affecting the firm's costs of alternative payment strategies.

We present this argument in the form of a model of the managerial choice of overdue wages owed to an employee. Under some conditions, the model generates multiple equilibria, and we study a symmetric game resulting in three: a stable equilibrium in which wage contracts are honored so that overdue wages are negligible, an unstable one with an intermediate level of wage contract violation, and a stable one with high arrears. The stable equilibria reflect institutional lock-in, tending to persist in the absence of massive shocks or coordination, and the unstable equilibrium represents a critical mass. The model explains not only why arrears tend to persist once they have become pervasive, but also why they tend to disappear quickly when they are not widely established. In this sense, the practice of honoring (or violating) contracts can be regarded as a social custom, a strategic complement, and an institution. ${ }^{4}$

An interesting property of well-established customs is that they tend to be unquestioned, taken for granted. Most employers do not treat delaying wage payments as a choice variable, and most employees do not wonder every payday whether they will receive their contractual wages. Despite their potential importance, these possibilities are usually not even considered. Our premise in this paper is that much can be learned about such customs by analyzing a case where they break down massively, such as Russia in the 1990s. The rise of overdue wages led to public outcry, with opinion polls ranking the issue as a top economic problem facing the country, but wage payments for many workers nevertheless remained unreliable for years. ${ }^{5}$ Besides the size and persistence of this contractual breakdown, our motivation for focusing on Russia is the fruitful testing ground it offers through the geographic variation within the country, the availability of linked employer-

\footnotetext{
${ }^{4}$ See Akerlof (1980) on social custom, Bulow et al. (1985) and Milgrom and Roberts (1990) on strategic complementarity, and Aoki (2001) on an institution as a set of equilibrium strategies in a game. Also closely related is the notion of convention, defined by Young (1993, p. 57) as "a pattern of behavior that is customary, expected, and self-enforcing."

${ }^{5}$ See Javeline (2003). Wage arrears have sometimes been ranked as the single biggest national problem, larger than low wages, despite the large decline and volatility of real wages through much of this period. Yet wage arrears usually imply only occasional, not frequent, nonpayment (as we discuss in Section 2, below). Russian workers evidently abhor the uncertainty about if and when they will be paid, and they value the reliability of regular wages as much as the actual wage level.
} 
employee panel data, and the presence of policy interventions providing instrumental variables for estimation.

Our empirical analysis of the Russian data begins by estimating a linear reaction function for wage contract violations, exploiting the unique features of our linked panel data that permit us to control both for correlated observables and for unobservable effects at the levels of the worker, the firm, and local labor market (defined narrowly as the district or rayon). To identify the endogenous interactions within local labor markets, we employ instrumental variables based on policy interventions affecting a subset of employers, in the spirit of Moffitt's (2001) and Bertrand et al.'s (2000) suggestions for identification of social interactions. Second, we directly estimate the four feedback loops - quits, effort, strikes, and legal penalties - that we hypothesize contribute to the strategic complementarity. Finally, we estimate a nonlinear form of the reaction function and, assuming symmetric competition in the local labor market and Nash behavior by managers, we calculate the three equilibria implied by the estimates.

Our analysis is closely related to interactions-based models in which interactions typically promote convergent practices, and, depending on parameters, may generate multiple equilibria. ${ }^{6}$ Empirical analyses of the phenomena face daunting identification problems, and they seldom estimate the possibility of multiple equilibria (Manski, 1993; Brock and Durlauf, 2001). In our paper, the interactions occur on multiple levels: the choices of firms whether to breach their contracts and the responses of workers and the legal regime to the breaches are all determined endogenously within local areas. Our case offers unusual opportunities to identify the interaction effects econometrically, and we exploit the availability of detailed observable characteristics, fixed effects, and instrumental variables. Unlike most studies of interactions-based models, which take a more reduced form approach, we are able to directly measure several feedback mechanisms that support strategic complementarities. Furthermore, we extend the usual linear analysis to a nonlinear case to assess the possibility of multiple equilibria.

\footnotetext{
${ }^{6}$ Among the many issues addressed in these models are social dynamics, technology choice, neighborhood effects, network externalities, strategic complementarities, and coordination problems. Blume and Durlauf (2001) survey the large literature.
} 
Interaction effects have received little attention in previous research on contract enforcement, frequently argued to be one of the institutional foundations of successful economies. ${ }^{7}$ Yet the common references to "rule of law," "business environment," and "investment climate” all imply an overall culture in which individual actions are influenced by the choices made by others. Similarly, a major theme in literature on the transition from socialism is the importance of marketsupporting institutions, including those related to contract enforcement (Murrell, 1992; Dewatripont and Roland, 1996; Greif and Kandel, 1995). But there has been little empirical analysis of these institutions, and no attention either to the role of interactions or to mechanisms that not only fail to support markets but serve to undermine them. ${ }^{8}$

Previous studies of Russian wage delays have established some of the empirical regularities that motivate our analysis (e.g., Alfandari and Schaffer, 1996; Gimpelson, 1998; Lehmann et al., 1999; Desai and Idson, 2000). We depart from this research in our hypotheses, analytical approach, and use of linked employer-employee data (rather than just household or firm surveys) over a much longer time period. Contrary to Layard and Richter (1995), we find it more useful to interpret wage arrears as a breach of contract rather than a flexible wage adjustment. Our approach is partly motivated by Earle and Sabirianova's (2002) findings of substantial variation across regions, variation both between and within firms, and high arrears even in well-performing firms (measured by profitability, productivity, hiring rate, output growth, employment growth, cash flow, or liquidity ratio), using data from 1994 to 1996. These results are only descriptive, however, while in this paper we develop and estimate an explicit model. Our model produces strategic complementarity and possible multiplicity of equilibria in wage delays, and we test its implications using new panel data from firm surveys we have organized and linked to employee information for

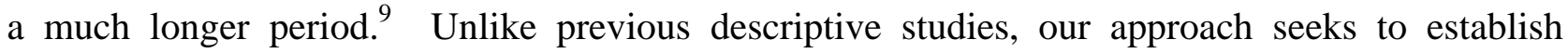
causality and therefore requires attention to identification problems that we take into account in

\footnotetext{
${ }^{7}$ See North (1990) and Hadfield (2004). Historical case studies of contract enforcement institutions include Greif et al. (1994) and Milgrom et al. (1990). The role of custom in the sharing rule in tenancy contracts is studied by Young and Burke (2001).

${ }^{8}$ More similar to our analysis are studies of multiple equilibria in the unofficial economy (e.g., Johnson et al., 1997) and in corruption (e.g., Bardhan, 1997).

${ }^{9}$ Our firm data cover 1991-1999 and our worker data cover 1994-2000. After 2000, the firm identification information is no longer available in the worker data, nor is the location of observations in the narrow geographic units (districts) of our analysis. Subsequent household data show that much of the decline in aggregate arrears had occurred by our last observation; in late 2003 , 26 percent of workers still reported arrears, down from about 30 percent in late 2000. Arrears have continued to attract public attention; see RFE-RL (2004), for instance.
} 
estimating the reaction function. We also estimate the hypothesized feedback loops and the equilibrium outcomes implied by the model. Thus, our paper brings together and contributes to research on the Russian economy and the broader literatures on interactions, institutions, contract enforcement, and transition.

The next section introduces our data. Section 3 presents a simple model to motivate our analysis of firm interactions and feedback loops. Section 4 describes our identification strategy and presents estimation results for the linear reaction function. Section 5 contains estimates of feedback loops through worker turnover, effort, strikes, and legal remedies. The possibility of a nonlinear reaction function is developed theoretically and estimated empirically in Section 6. Section 7 concludes with a brief summary and discussion of welfare implications.

\section{Data}

\subsection{Data Sources}

Our model analyzes the determination of wage arrears in a particular employment relationship for a firm and a worker. The data required to test the model include detailed information on both sides of the relationship, which we obtain from several sources. The source of the worker data consists of the 1994-2000 waves of the Russian Longitudinal Monitoring Survey (RLMS), a publicly available household panel based on the first national probability sample drawn in Russia. ${ }^{10}$ We have extended these data by using confidential information provided by most working respondents on their employers (frequently the name of the firm) to identify firms and the industries in which they operate. This allows us to control for constant firm and industry heterogeneity and to construct reliable measures of job mobility and tenure.

A second major data source is a detailed survey of agricultural and industrial employers that we carried out to collect information on wage arrears, quits, strikes, legal penalties, and other variables for the years 1991-1999. ${ }^{11}$ Our sampling frame was every identifiable employer of RLMS respondents, thus constituting a national probability sample of employers in industry and

\footnotetext{
${ }^{10}$ The RLMS data we use are results of longitudinal surveys of about 10,000 individuals in late fall of 1994, 1995, 1996, 1998, and 2000. Information on wage arrears is unavailable before 1994, and availability of links to firms and precise geographic location restrict our attention in this paper to 1994-2000.

${ }^{11}$ This data set "Inside the Transforming Firm" is available from the authors on request.
} 
agriculture, with selection probability proportional to employment size. ${ }^{12}$ Unlike most surveys of firms, our procedure did not replace nonrespondents, and great efforts were expended to include every firm. As a result of this procedure, the response rate is high: 64 percent among industrial firms (522 firms) and 73 percent among agricultural firms (75 firms). Missing values reduce the sample to 560 (486 industrial and 74 agricultural firms). We also add regional data from the Russian Labor Ministry Inspection Service on Labor Code violations and case outcomes, from which we construct regional measures of the effectiveness of legal enforcement.

\subsection{Measuring Wage Contract Violations}

Our measure of wage contract violations is the stock of overdue wage debt owed by a particular employer to a particular employee. Following the standard practice in Russia—among both workers and firms-we express these arrears in terms of the number of monthly wages the firm owes the worker. ${ }^{13}$ The RLMS asks this question directly, and the answers provide the measure of individual wage arrears (denoted $\omega$ ) that we analyze.

There are no good measures of arrears prior to 1994, but from anecdotal reports it is clear that they were negligible in the Russian economy before $1993 .^{14}$ As shown in Table 1 , however, the unconditional mean of $\omega$ already exceeded one monthly wage in 1994, and it rose in 1996 and again in 1998 before falling in 2000; the distribution of the variable shows pronounced rightward shifts in 1996 and 1998. The mean level of $\omega$ is slightly lower in the public sector, which is defined on the basis of industries dependent on the state (federal, regional, and municipal) budgets in Russia: defense industries, municipal utilities, health services, social work, education, culture and art, science, public administration, military, and public order and safety. However, it is significantly higher in the defense sector, comprising defense manufacturing and the military, categories we distinguish because they are paid entirely from the federal budget and thus should be independent of local decision-making.

\footnotetext{
${ }^{12}$ This statement is conditional on the RLMS sampling, which involves a two-stage geographic stratification procedure followed by random drawing of households (residences).

${ }^{13}$ Wages are paid monthly in Russia, and managers usually refer to the number of monthly wage bills when discussing arrears.

${ }^{14}$ Official data on wage arrears in Russia are incomplete and inconsistent in coverage, but they show generally similar patterns over time as the RLMS data. See, for instance, Goskomstat (1999).
} 
The proportion of workers with two or more months of arrears was already about 25 percent in 1994, and it had increased to nearly 44 percent by 1996 and 50 percent by late 1998. Conditional on having arrears, the expected magnitude rose from 3.3 months in 1996 to more than 4.8 months in 1998. While this debt represents a large fraction of a worker's income, note that the increase of about 1.5 monthly wages over this 2-year period implies the loss of only about 0.75 monthly wages each year, or about 6 percent of annual income. Moreover, workers could hope to receive at least some of their back wages in the future, and indeed the conditional mean fell to 4.2 monthly wages in 2000, and the fraction with arrears fell from 62 to 27 percent.

In our empirical tests of the model's hypotheses, we construct a measure of local arrears $(\Omega)$ from the RLMS by aggregating $\omega$ up to the district (rayon) level, each time omitting the particular firm for which the individual worker is employed. While analyses of Russian regions are frequently conducted at the level of the oblast, we feel that the district much better reflects the scope of the local labor market. ${ }^{15}$ Table 1 illustrates the substantial variation across selected districts, some with trivial levels of arrears and others with up to 12 monthly wages per employee.

\subsection{Sample Characteristics}

Table 2 summarizes worker and job characteristics of employees in the RLMS sample. 36.7 percent are employed in the public sector and 5.3 percent in the defense sector. Definitions of most individual attributes (such as gender, age, job tenure, years of schooling, employee ownership, occupation, and industry) are straightforward. The hourly wage rate is computed as the ratio of the contractual wage to the usual hours of work in the previous month. ${ }^{16}$ Family income includes income (monetary and in-kind) received during the past month from all jobs, as well as retirement and unemployment benefits of other members of the household. All income measures are calculated in constant December 2000 prices using the monthly Consumer Price Index (CPI).

\footnotetext{
15 The Russian Federation has 89 oblasts and other constituent subjects, some of them larger than Texas. The next lower administrative level is the rayon, of which there are 22 per oblast on average, thus roughly equivalent to a US county. Our data contain 52 rayons, thus 52 different values of $\Omega$ in each year of the RLMS sample.

${ }^{16}$ Wage arrears produce high volatility in the measured wage. In a given survey month, the reported wage is frequently zero (as high as 30 percent of responses by workers); it will be lower than the contractual wage when new wage debts are incurred and higher than the contractual wage when they are paid off. To measure the contractual wage, we added questions to the RLMS in 1998 and 2000, and for the earlier years we have followed Earle and Sabirianova (2002), imputing it as the ratio of the total wage debt to the number of monthly wages owed $(\omega)$.
} 
Previous studies have found that wage arrears are more common among men, negatively associated with schooling, and positively related to age and job tenure; these may reflect skill specificities, mobility costs, and outside opportunities. ${ }^{17}$ Workers with arrears are more likely to be small shareholders and to have lower wages and family incomes. Craft workers, operators, and assemblers tend to experience the highest rates, while managers have the lowest-although the rate is high even for this occupation. Wage arrears are found in firms with a high level of financial and operating performance, as well as those performing poorly. Finally, variation across industries is large, with higher incidence and magnitude in agriculture, defense and heavy industrial sectors, as well as in services financed through the state budget (education and health). In a new and rapidly developing sector like banking and finance, however, arrears are very small.

Summary statistics for the firm sample also appear in Table 2. Compared with Table 1, mean $\omega$ and $\Omega$ are somewhat smaller in the firm data (although variation over time in these variables is quite similar across sources). There are two reasons for the difference: the time span begins earlier in the firm survey (as early as 1991 for some firms), and the firm survey excludes most of the public sector. The latter consideration prevents us from using the firm data to follow the instrumental variables strategy in Section 4, and the firm survey data are used only in the estimation of feedback loops associated with costs of arrears.

Table 2 also shows control variables in the firm sample: union density, fringe benefits, training costs, industry, local type, and legal environment. These variables, as well as the quit rate and incidence of strikes and legal penalties, are introduced in Section 5.1 below.

\section{A Model of Wage Arrears}

This section presents a stylized model of managerial decisions about wage delays that focuses attention on interactions within local labor markets. The model is also useful as a framework for considering several types of feedback loops that may support the use or nonuse of the late payment practice, for laying out critical assumptions in the analysis, and for suggesting important factors to control for in the empirical work. Although arrears decisions have an important dynamic component, including the expectations of managers and workers concerning

\footnotetext{
${ }^{17}$ See Lehmann et al. (1999), Desai and Idson (2000), and Earle and Sabirianova (2002).
} 
each other's behavior and the evolution of exogenous determinants, our static model captures the essential features of arrears we would like to describe. ${ }^{18}$

The main result of the model is a general reaction (or best-response) function that relates an individual firm's arrears behavior to the prevalence of arrears in the firm's local labor market. This reaction function is assumed to apply only to firms in the nonpublic sector of the economy, as public sector arrears are affected by government decisions - assumptions that we use in our identification strategy to empirically estimate the reaction function in Section 4.

\subsection{Returns and Costs to Wage Arrears}

Consider a nonpublic firm whose manager chooses the level of back wages $\omega$ owed a particular employee in a particular time period to maximize $\pi$, which may represent either the firm's profit or the manager's private net benefits. $\omega$ is essentially an involuntary loan from the worker to the firm, and we assume it earns the manager a gross per-period return of $R(\omega, X)$, with marginal return $R_{\omega}(X)=r(X)$ assumed to be constant in $\omega$ but varying according to some characteristics of the firm, $X$ (assumed to be scaled so that $r_{x}>0$ ). The relevant characteristics may include the liquidity needs of the firm, the effective interest rate that it faces in borrowing from other sources, and the ability of the manager to appropriate the returns by diverting the funds to projects earning private benefits. In Russia until August 1998, for example, poorly monitored managers could invest spare funds in short-term government treasury bills (GKOs), earning rates up to 150 percent. In such situations, wage arrears are likely to be more attractive to managers who can relatively easily channel the extra cash flow to their own purposes.

While it is not difficult to appreciate the potential returns that the firm might obtain from breaching its wage contracts, there are also costs of not fulfilling these obligations. The potential costs include increased worker turnover, lowered effort, and higher probabilities of strikes and legal penalties. ${ }^{19}$ In each of these cases, we argue that the associated costs are positive functions of $\omega$, but that the marginal cost is attenuated by the magnitude of arrears in the rest of the firm's local

\footnotetext{
${ }^{18}$ In addition, it is problematic to estimate a dynamic model because of the shortness and low frequency of the time series available.

${ }^{19}$ If $\pi$ is private benefit rather than profit, these costs to the firm reduce the rents that the manager can take out of the firm, implying that they should matter to the manager as well.
} 
labor market, $\Omega$. The rationale for each type of cost is fairly straightforward, and we provide evidence on the form of the costs in the empirical analysis below.

A first type of cost arises because delaying wages may increase quits, if the worker responds by moving to another job or exiting the labor force altogether. We assume that quits impose costs $Q$ of replacement, associated with the need for hiring, screening, and training. The quit decision is not modeled explicitly, but we assume the manager knows the probability of the worker quitting as a function of $\omega$ and $\Omega$, and we hypothesize a negative impact of $\Omega$ on the worker's quit response to arrears and thus on the firm's marginal cost of arrears. Higher $\Omega$ reduces the quit responsiveness because it reduces the attractiveness of mobility to other firms, and it may also increase the worker's acceptance of the unreliability of wage payments. Because workers differ in their mobility costs and outside opportunities, we permit the quit function to vary with a set of characteristics such as current compensation, firm-specificity of skills, mobility costs, and local labor market conditions included in the $Z^{Q}$ vector, so that $Q=Q\left(\omega, \Omega, Z^{Q}\right)$, with $Q_{\omega}>0$ and $Q_{\omega \Omega}<0 .^{20}$

Wage delays may also affect productivity. If morale declines and if effort is not perfectly observable, then workers may be more likely to shirk and, where they have some discretion over hours of work, to reduce their hours. We summarize these agency issues as $E$ for “effort costs” and assume that the manager expects that higher arrears may reduce productivity through mechanisms as in efficiency wage theory. Such costs are likely to vary with worker characteristics, $Z^{E}$, including the importance of morale for productivity, the difficulty of monitoring, and the degree of independence the worker has in decision-making. We hypothesize that the negative effort effect is attenuated by wage arrears in the rest of the firm's local labor market, $\Omega$, as the worker's decisions are influenced by outside alternatives (for instance, if caught shirking and fired) and by perceptions of the practice's fairness or legitimacy (which are influenced by social interactions). The effort costs may thus be written as $E\left(\omega, \Omega, Z^{E}\right)$, with the properties $E_{\omega}>0$ and $E_{\omega \Omega}<0$.

\footnotetext{
${ }^{20}$ Firms wanting to reduce employment without layoffs may use wage arrears to induce quits, but we would again argue that workers' responses will vary with $\Omega$, and the relevant complementarity condition $Q_{\omega \Omega}<0$ remains the same. Another possibility is that arrears reduce quits because quitters forgo their unpaid wages, in which case $Q_{\omega}<0$, but we would expect $Q_{\omega}$ to be still lower at higher $\Omega$, so that again $Q_{\omega \Omega}<0$. In practice, we estimate $Q_{\omega}>0$, as hypothesized in the model.
} 
Another type of cost results if arrears increase strikes and other forms of protest behavior, resulting in costs summarized by $S\left(\omega, \Omega, Z^{S}\right)$. Again, we assume a positive relationship that is attenuated by arrears in the local labor market, such that $S_{\omega}>0$ and $S_{\omega \Omega}<0$. The argument is that workers view arrears in the context of what is "normal" in their environment (as in "pattern bargaining”), and they are less likely to protest their own arrears when their friends and neighbors are also being paid late. The probability of such behavior is likely to be a function of other characteristics of the firm and worker, particularly the extent of unionization, included in a set of exogenous variables $Z^{S}$.

A final type of cost arises because wage arrears are violations of legal contracts, resulting in possible legal penalties and associated costs $L\left(\omega, \Omega, Z^{L}\right){ }^{21}$ Again, we hypothesize that the probability of legal costs is positively related to the level of arrears in the firm, but that the marginal effect is lower in jurisdictions with higher arrears, such that $L_{\omega}>0$ and $L_{\omega \Omega}<0$. One motivation for this hypothesis is that the legal system in a jurisdiction may become congested with arrears cases, reducing the probability of punishment, similar to Sah's (1991) analysis of the probability of punishment falling with the crime rate. Furthermore, in a high arrears environment, breaches of the wage contract may be perceived as normal and legitimate, and law enforcement officials may therefore be less likely to press cases and assess severe penalties against infractions; workers may also be more pessimistic about the chances of resolving the problem through legal channels. In the analysis of legal penalties and wage arrears, it is also important to take into account regional variation in the effectiveness of the legal system stemming from factors other than the congestion and lawsuit filing effects, $Z^{L}$.

To summarize, managers face four costs of wage arrears: $E, Q, S$, and $L$, each of which is a function of $\omega, \Omega$, and some shift variables, the vector $Z$. Although the costs are not directly observable, some proxies for the underlying behavior can be measured in our empirical work. For convenience in the exposition of the rest of the model, we consider the sum of the four costs $C(\omega$, $\Omega, Z)=E\left(\omega, \Omega, Z^{E}\right)+Q\left(\omega, \Omega, Z^{Q}\right)+S\left(\omega, \Omega, Z^{S}\right)+L\left(\omega, \Omega, Z^{L}\right)$, where $Z=\left(Z^{E}, Z^{Q}, Z^{S}, Z^{L}\right)$ is a vector of other factors such as worker compensation and fringe benefits, skill specificity, search

\footnotetext{
${ }^{21}$ The Russian Labor Code explicitly requires on-time payment of wages, and firms may be called to account by the civil courts (when workers file a lawsuit) or the Ministry of Labor's Inspection Service. The latter has been known to fine managers as well as firms, and, more rarely, to order managerial dismissal.
} 
costs, difficulty of monitoring, strength of worker organization, functioning of the legal system, and characteristics of the local labor market. The assumption that $C_{\omega \Omega}<0$, marginal cost declining in local labor market arrears, is the crucial mixed partial derivative condition for strategic complementarities to emerge (e.g., Milgrom and Roberts, 1990). In our empirical analysis in Section 5 below, we test this assumption directly for each component of costs: the negative effects of a worker's arrears on her morale and work hours should decline in absolute value with the arrears level in the local labor market, and the positive effects of arrears on quits, strikes, and legal penalties should be attenuated by local labor market arrears.

\subsection{The Reaction Function: $\varpi=f(\Omega, X, Z)$}

The manager chooses $\omega$ to maximize the expected net return $\pi$.

$$
\max _{\{\omega\}} \pi=R(\omega, X)-C(\omega, \Omega, Z),
$$

where $\omega$ is the amount of back wages owed to the worker and $\Omega$ is the average amount of wage arrears in the local labor market outside the firm. The corresponding first and second order conditions for the manager's problem are $r(X)=C_{\omega}(\varpi, \Omega, Z)$ and $-C_{\omega \omega}<0$.

The reaction function, the best response to other firms' choices, can be derived as

$$
\varpi=f(\Omega, X, Z) .
$$

Total differentiation of the first order condition yields

$$
r_{X} d X-C_{\omega \omega} d \omega-C_{\omega \Omega} d \Omega-C_{\omega Z} d Z=0
$$

Making use of the assumptions and the second order condition, we can derive the following comparative static results for the impact on $\omega$

$$
\frac{d \omega}{d X}=\frac{r_{X}}{C_{\omega \omega}}>0 \text { and } \frac{d \omega}{d Z}=\frac{-C_{\omega Z}}{C_{\omega \omega}}<0 .
$$

Thus, wage arrears should be positively related to the firm's cost of capital and to the ability of managers to appropriate cash flow and earn private benefits. They should be negatively related to the difficulty of monitoring the worker, to the value of the worker's outside alternatives, to the strength of worker organization, and to the effectiveness of the legal system. Finally, factors that reduce quit rate increase the probability of having wage arrears (specific human capital, employee ownership, high search and mobility costs, etc.). 
Differentiating the reaction function (2) with respect to $\Omega$ (while holding constant the variables in $X$ and $Z$ ) yields

$$
\frac{d \omega}{d \Omega}=-\frac{C_{\omega \Omega}^{(-)}}{C_{\omega \omega}}>0 .
$$

Thus, a direct implication of our model is that wage payment decisions exhibit positive neighborhood effects. In the next section, we present our empirical estimates of a linear reaction function, followed by an empirical analysis of the feedback loops (in Section 5) and an example of a nonlinear reaction function implying the possibility of multiple equilibria (in Section 6).

\section{Estimating the Linear Reaction Function}

Our first tests of the model focus on the positive slope of the reaction function $(\partial \omega / \partial \Omega>0)$. We also examine the model implications that proxies for $X$ raise $\omega$ and that proxies for $Z$ lower $\omega$, while postponing analysis of the feedback loops until the next section. We first discuss our identification strategy and then present results.

\subsection{Identification Strategy}

To test for positive feedback in the reaction function, we assume a linear functional form for Equation (2). Estimating the function directly by ordinary least squares (OLS) may produce the standard “reflection” problems of any model of social interactions (Manski, 1993; Moffitt, 2001). As an illustration, consider the following model of endogenous interactions for two firms (for simplicity, each with one employee), indexed by $i$ and $k$ :

$$
\begin{aligned}
& \omega_{i j t}=\beta_{0}+\beta_{1} \Omega_{(-i) j t}+\beta_{2} X_{i j t}+\beta_{3} Z_{i j t}+\tau D_{t}+u_{i j t} \\
& \omega_{k j t}=\beta_{0}+\beta_{1} \Omega_{(-k) j t}+\beta_{2} X_{k j t}+\beta_{3} Z_{k j t}+\tau D_{t}+u_{k j t},
\end{aligned}
$$

where $\omega_{i j t}$ is the number of unpaid monthly wages of firm $i$ in district $j$ in period $t ; \Omega_{(-i) j t}$ is the level of wage arrears in the rest of the firm's local labor market (district) $j$ in period $t ; X_{i j t}$ and $Z_{i j t}$ are the vectors of observable factors affecting returns to and cost of using wage arrears, respectively; $D_{t}$ is a set of year dummy variables; and the $u$ 's are error terms.

A first potential identification issue in estimating the wage arrears reaction function is the possibility that the reference group is endogenous. Analogously to the choice of peer group in studies of teenage behavior (e.g., Evans et al., 1992), it is possible that firms and workers sort 
themselves across districts with respect to their returns, costs, and tolerance of arrears. The clustering of arrears within districts might merely reflect the tendency for similar agents to locate close to one another. Our inclusion of district-level fixed effects controls for this possibility, but in any case such geographic sorting seems quite implausible, particularly in the Russian case. An oftnoted feature of Russian labor markets is the low geographic mobility of labor, explained by information problems, poorly functioning housing markets, and lack of liquidity (Mitchneck and Plane, 1995; Andrienko and Guriev, 2004). All evidence implies that Russian regions are poorly integrated, and worker mobility across regions can act only slowly to affect regional differences.

A second identification problem arises if omitted unobservables are correlated with $\Omega$ and also correlated across firms and workers within a local labor market. Examples of such omitted variables that could produce $\operatorname{Cov}\left(u_{i j t}, u_{k j t}\right) \neq 0$ in our model include differences across districts in resources, demand conditions, legal environment, or social norms such as tolerance towards contract violation. The problem of correlated unobservables that are time-invariant may be handled with local labor market (district) fixed effects $\theta_{j}$. There could also be correlated timeinvariant unobservables at the levels of firms and of workers that we account for by including firm and worker fixed effects.

The problem of correlated unobservables becomes more complex if they are not timeinvariant, so that for example there are common district-level shocks, or if error terms are correlated due to firm interdependence in the level of wage arrears: $\quad \omega_{i j t} \Rightarrow \Omega_{(-k) j t} \Rightarrow \omega_{k j t} \Rightarrow \Omega_{(-}$ ${ }_{i j j t} \Rightarrow \omega_{i j t}$. In the spirit of Moffitt (2001), our identification strategy is to search for exogenous interventions that alter wage arrears for some workers but not for others. We exploit the fact that nonpayment of wages in the public sector is driven by a different process-governmental financing and revenue-sharing decisions - than wage delays in the nonpublic sector, which are driven by the considerations in our model. Indeed, while data on the early period are scarce, we believe the initial burst of arrears in Russia was caused by the sequestration of budgetary funds by the Ministry of Finance in the early and mid-1990s. Only very incomplete accounts of the extent of sequestration are available, but according to many observers the amounts were large. ${ }^{22}$ According

\footnotetext{
${ }^{22}$ The motive for sequestration was to reduce the budget deficit and inflation following price liberalization in 1992; the deficit target figured strongly in IMF loan agreements at the time, and some policymakers even boasted of sequestration as a clever way to satisfy conditionality.
} 
to the Institute for the Economy in Transition (1994, p. 35), for example, every expenditure line in the fourth quarter of the 1993 federal budget was sequestered by 20 percent. Rather than shutting the government down, as sometimes happens during budgetary disputes in the US, the Russian government continued to operate, government contractors continued to supply, and state employees continued coming to work even when they began to be paid irregularly. Unfortunately, detailed data on these early stages of wage arrears are unavailable.

This discussion implies that an identification solution may be to use arrears practice in the public sector to identify neighborhood effects in the nonpublic sector. Assuming two nonpublic firms, $i$ and $k$, and one aggregated public sector firm, $p$, the model becomes

$$
\begin{aligned}
& \left\{\begin{array}{l}
\omega_{i j t}=\beta_{1} \Omega_{(-i) j t}+\beta_{2} X_{i j t}+\beta_{3} Z_{i j t}+\tau D_{t}+\theta_{j}+\varepsilon_{i j t} \\
\omega_{k j t}=\beta_{1} \Omega_{(-k) j t}+\beta_{2} X_{k j t}+\beta_{3} Z_{k j t}+\tau D_{t}+\theta_{j}+\varepsilon_{k j t} \\
\omega_{p j t}=\beta_{2 p} X_{p j t}+\beta_{3 p} Z_{p j t}+\tau_{p} D_{t}+\theta_{p j}+\varepsilon_{p j t}
\end{array}\right. \\
& \operatorname{Cov}\left(\varepsilon_{i j t}, \varepsilon_{p j t}\right)=\operatorname{Cov}\left(\varepsilon_{k j t}, \varepsilon_{p j t}\right)=0,
\end{aligned}
$$

where coefficients are permitted to vary between the nonpublic and public sector equations. The identifying assumption is that $\Omega_{(-p) j t}$, the level of wage arrears in the rest of the aggregated public sector firm's district $j$ in period $t$, does not enter the equation for $\omega_{p j t}-$ in other words, that wage arrears in the public sector are determined by bureaucratic decisions in the federal and regional governments that are unrelated to arrears of nonpublic firms in the local area. ${ }^{23}$

In these Equations (7), $\Omega_{(-i) j t}$ equals the sum of average wage arrears in the public and nonpublic sectors, weighted by the share of workers in the corresponding sectors:

$$
\Omega_{(-i) j t}=\frac{1}{N_{j t}}\left(\sum_{k \neq i} \omega_{k j t}+\sum_{p} \omega_{p j t}\right)=\bar{\omega}_{n j t}\left(1-n_{p j t}\right)+\bar{\omega}_{p j t} n_{p j t},
$$

where $\bar{\omega}_{p j t}$ and $\bar{\omega}_{n j t}$ are the average wage arrears in the public and nonpublic sectors respectively (again excluding firm $i$ ), and $n_{p j t}$ is the share of workers in the public sector. The first term in $\Omega_{(-i) j t}$ is endogenous, while the second term is exogenous. Therefore, we can employ $\bar{\omega}_{p j t}=\Omega_{p j t}$ and $n_{p j t}$

\footnotetext{
${ }^{23}$ Note that this model assumes that the public sector forms part of the reference group for nonpublic firms (but not vice versa) because the response of nonpublic employees to arrears depends partly on their observations and opportunities in the public sector. As justification, we note that mobility between the two sectors is high: about half of job-to-job mobility from a public employer is to the nonpublic sector and a quarter of the mobility from a nonpublic employer is to the public sector. Moreover, households are frequently composed of earners from both sectors: among multi-earner households in our whole sample, 42.2 percent have only nonpublic sector employees, 15.0 percent have only public sector employees, and 42.8 percent are mixed.
} 
as instruments, capturing both the magnitude of average arrears that appear exogenously and the relative share of this exogenous component in total regional arrears.

The identifying assumption of no interaction effects in the public sector is more likely to hold for the parts of the public sector that are funded exclusively by the federal government. For this reason, we also examine the results using an alternative set of instrumental variables, the average local arrears in the defense sector and the share of workers in the defense sector in district $j$ in year $t$. These can be motivated by a similar decomposition of Equation (8) into the defense and nondefense parts of the public sector. ${ }^{24}$

The assumption of no feedback from the nonpublic to the public sector is also more likely to hold for the public sector outside of the local labor market at the national or aggregated regional levels. As a further extension, therefore, we also employ a set of instruments inspired by Bertrand et al. (2000): the public sector arrears in Russia as a whole and in large federal regions together with interactions of these variables with the share of public sector workers in the local district, $n_{p j t}{ }^{25}$ The argument is that even if $\Omega_{p j t}$ were partly subject to feedback from nonpublic arrears $\Omega_{n j t}$ in the same district, $\Omega_{p t}$ at the national or federal region level would not be.

\subsection{Results}

Our discussion of identification issues implies the value of alternative estimation approaches. We first provide OLS estimates of the reaction function, then in turn add district and firm fixed effects (FE), and both firm and worker FE. ${ }^{26}$ Finally, we employ various combinations of instrumental variables (IV). Because both firms and workers are nested within districts, the firm and worker FE specifications also remove any fixed differences across districts. In all cases, we compute robust standard errors adjusted for clustering within local areas or districts.

The basic OLS and FE estimation results for the linear reaction function in the nonpublic sector are shown in Panel A of Table 3; Panel B adds a full set of interactions of year dummies with federal region indicators. The estimated $\beta$ (the coefficient on $\Omega_{j t}$ ) is positive and statistically

\footnotetext{
${ }^{24}$ A disadvantage of the defense sector instruments is that 3 of 52 districts have no defense sector employees in the sample. Small sample sizes more generally may make these instruments noisy, resulting in weak relationships with district arrears.

${ }^{25}$ Russia has 7 large federal regions formed on the basis of similar economic and climatic conditions among neighboring oblasts. We have about 7 local districts per federal region in our data.

${ }^{26}$ Estimated reaction functions with only worker FE yield similar results and are available upon request.
} 
significant in all eight specifications. In Panel A, the range of magnitudes is from about 0.4 (with district FE) to 0.8 (with firm FE). In each case, the fixed effects are highly significant. In particular, the industry effects are highly significant (in the OLS and district FE specifications), and the district FE have an $F$-statistic of 1992. These results imply that the data contain substantial unobserved heterogeneity in the cross-section, even when controlling for year effects (which are also statistically significant) and many other variables. After controlling for district FE and for either firm FE alone or both firm and worker FE together, the estimated $\beta$ remains sizable and statistically significant. The Panel B specifications are still much more demanding in relying on deviations from the federal region-year mean to identify interaction effects, but the estimated effects remain positive and statistically significant. These results provide some initial evidence of strong neighborhood effects in the violation of wage contracts.

The other variables in Table 3 represent $Z$ variables, worker characteristics affecting the firm's costs of delaying wages. The results are quite similar across specifications as well as to results in previous research using earlier data: wage arrears are higher for men, but they vary little with schooling, age, or family income. The negative effect of tenure is consistent with the interpretation that longer tenured workers have relatively poor outside alternatives (Lehmann et al., 1999). The hourly wage has a negative coefficient, a relationship which Desai and Idson (2000) interpret as suggesting that managers delay wages to less productive workers. A final result is the positive impact of small share ownership, which may imply that managers delay wages to acquire shares from their workers (Earle and Sabirianova, 2002).

Results for IV specifications of the reaction function for the nonpublic sector are presented in Table 4. Aside from instrumenting $\Omega_{j t}$, the specifications are otherwise the same as in Table 3; the results for other variables are quite similar, so we omit them to save space. We show results for 5 alternative sets of the instruments. Specification 1 includes $n_{p j t}$, the district share of employees working in the public sector, and $\Omega_{p j t}$, the average arrears among public sector employees in the district. Specification 2 includes the district share of employees working in the defense sector and the average arrears among defense sector employees in the district. Specification 3 uses the federal region public arrears (excluding the given local district) and their interaction with $n_{p j t}$ as the 
instruments. In Specifications 4-5, national public sector arrears are interacted with the share of public sector workers in the district $n_{p j t}$ and with a quadratic in $n_{p j t}$ to take into account different functional relationships between national and local public sector arrears. In the last three specifications, we do not treat $n_{p j t}$ as an instrument, instead including it as a regressor to control for the possibility that public sector share is directly correlated with local economic shocks. The columns on the left side of the table include district FE, while those on the right include firm FE; results with worker FE and with both firm and worker FE are qualitatively similar.

In each specification in Table 4 , the estimated coefficient on $\Omega_{j t}$ is positive, large, and statistically significant at least at the 10 percent level, lying in a range from 0.61 to 0.96 . The local public employment share $n_{p j t}$ typically has a large positive coefficient, although it is not always precisely estimated. In each case, the first-stage results show that the excluded instruments are not weak and significantly increase $\Omega_{j t}{ }^{27}$ The value of the Hansen $J$ statistics suggest that the data marginally reject exogeneity of $n_{p j t}$ and $\Omega_{p j t}$, which might imply some reverse feedback from the nonpublic to the public sector, but the data fail to reject exogeneity of defense sector instruments with firm FE (Specification 2), as well as in every case with multiple instruments based on higher levels of geographic aggregation (Specifications 3 and 5). ${ }^{28}$ These results again imply strongly positive local interactions in the nonpublic sector, as our model predicts.

\section{Estimating the Feedback Loops}

This section presents empirical estimates of feedback loops that create strategic complementarities across firms in their wage arrears decisions, constituting indirect tests of the complementarity hypothesis. We draw upon both the worker and the firm data to construct proxy variables for the four types of costs of arrears discussed in the model, and summary statistics for these variables are displayed in Table 2. The variables “actual hours of work," "desire to switch jobs,” and "job separations” are measured from the RLMS, while "quit rate,” "strikes and other

\footnotetext{
${ }^{27}$ The first stage results in specification (3)-(5) show that local arrears are strongly correlated with $n_{p j t}$ and federal region public sector arrears (the national arrears drop out of specifications (4)-(5) because they are collinear with the year effects). The sign of the interaction term is negative, implying that higher- $n_{p j t}$ districts tend to be allocated less of the national and regional arrears than lower- $n_{p j t}$ districts, which could result if $n_{p j t}$ is correlated with political influence or scale economies.

${ }^{28}$ We have also estimated Table 3 specifications for the public and defense sectors as function of $\Omega_{j t}$. The results (which are upward-biased due to the absence of an instrument to purge common unobserved shocks) show much weaker although statistically significant interactions in the public sector, but they show no significant feedback to arrears in the defense sector; the coefficient estimates with district FE are 0.298 in the former case and 0.098 in the latter.
} 
forms of protest," and "legal penalties" are drawn from the enterprise survey. We argue that the first two variables - actual hours of work and desire to switch jobs-proxy for morale and job satisfaction which are likely to influence work effort.

We analyze two measures of worker turnover. The first, based on the RLMS panel, defines a job separation as no longer working for the employer two years later. This includes all types of separations, but available evidence strongly indicates that the share of involuntary separations is very low in Russia-generally less than 10 percent (e.g., Brown and Earle, 2003). The second measure, derived from the firm survey data, includes voluntary separations only, is expressed as a ratio to average firm employment, and refers to a one-year period.

The final two potential costs of arrears are also measured at the firm level. "Strikes" refer not only to formal work stoppages but also to other forms of protests, such as hunger strikes and work slowdowns. The data imply they are much more common in firms reporting wage arrears than in those not, and wage arrears were by far the most commonly cited reason for strikes by firms reporting them in response to a direct question. "Legal penalties” refer specifically to fines for wage arrears, which are imposed by either a civil court or the Labor Inspection Service. As Table 2 shows, the incidence of both variables is very low in the early 1990s but becomes more substantial in the second half of the decade.

Recall from Section 3.1 the model assumptions of $C_{\omega}>0$ and $C_{\omega \Omega}<0$ : the costs of not paying wages exhibit positive feedback in the sense that the costs of arrears are reduced on the margin when other firms in the local labor market tend to have higher arrears. Each type of cost represents a feedback loop contributing to self-propagation of the wage arrear practice.

The critical assumption of a negative cross-partial derivative may be directly tested using an interaction term in each equation. The relationship between the costs of using wage arrears and the wage arrears environment can be presented in linear form as follows:

$$
C_{i j t}=\beta_{\omega} \omega_{i j t}+\beta_{\Omega}{ }_{(-i) j t}+\beta_{\omega \Omega} \omega_{i j t}{ }_{(-i) j t}+\gamma Z_{i j t}+\tau D_{t}+\theta_{j}+\varepsilon_{i j t},
$$

where $C_{i j t}$ are proxy measures for wage arrears costs such as hours of work, desire to switch jobs, quits, strikes, and legal penalties. 
Table 5 shows estimates from the worker survey data for the functions with desire to change jobs, hours of work, and job separation as dependent variables. The impact of $\omega$ on a worker's hours and desire to switch jobs is reduced by $\Omega$ (so that $E_{\omega \Omega}<0$ ). Computing $\partial($ Hours $) / \partial \omega$ at alternative levels of $\Omega$, we find that workers in low- $\Omega$ regions reduce their hours in response to their own arrears, so that if $\Omega=0$, hours fall 1.87 hours per month for each one month increase in $\omega$. But $\partial$ (Hours) $/ \partial \omega$ falls as $\Omega$ rises, and at $\Omega=8.9$ months, the effect vanishes entirely. Similarly, the probability that an individual reports a desire to switch jobs increases by 2.2 percent for each month of $\omega$ in regions where $\Omega=0$. Given an overall average probability of 38 percent, this effect implies that an individual who has eight months' arrears and lives in a low arrears region would be 50 percent more likely to desire a job change compared to an otherwise identical neighbor with no wage arrears. But the effect declines with $\Omega$ such that the point estimates suggest it becomes negligible at about $\Omega=11$.

Table 5 also shows the estimated job separation function using individual data. Again, the results imply $Q_{\omega}>0$ and $Q_{\omega \Omega}<0$ for this component of costs. When $\Omega=0$, the separation probability is estimated to increase by nearly 1 percentage point for each one-month rise in $\omega$, and as $\Omega$ rises the estimated response to $\omega$ declines, becoming negative after $\Omega=8$. These estimates are again consistent with our hypothesis that wage arrears are strategic complements for managers of firms operating in the same local labor market.

Table 5 results concerning the vector of $Z$ controls in the regressions are fairly standard: the hours equation implies that both the hourly wage rate and nonlabor (family) income have a negative estimated effects, while male gender, schooling, and age are all positively associated with hours. The regression for desire to switch jobs shows that the probability declines with the contractual wage and with job tenure. In the quit function, results for the $Z$ controls show that male gender is positively associated while schooling and tenure are negatively associated with the quit probability.

Turning to the feedback functions using the firm survey data, we specify the $Z$ vector to include dummies for industry, year, and type of location (four city-type categories) in all equations. The quit rate and strike probability functions also include union density (percentage of employees 
who are union members), provision of fringe benefits (training, kindergartens, and housing), and training costs for new employees (measured as number of days required in initial training). The legal penalties equation includes proxies for the legal environment in the subject of the Russian Federation drawn from the Ministry of Labor's Inspection Service in 1997. One variable is the ratio of uncollected fines to the total number of fines assessed on managers because of labor violations, which we interpret as reflecting (inversely) the strength of the legal system in carrying out at least those punishments it does assess: managers would have relatively little to fear in regions where this ratio is high. A second measure is the fraction of cases where wage arrears were paid off after they were found by (or reported to) the Inspection Service. Summary statistics for all these controls are reported in Table 2.

For all three dependent variables, the results in Table 6 show that $\Omega$ tends to lessen the impact of $\omega$ on the costs to the firm of using arrears: $Q_{\omega \Omega}<0, S_{\omega \Omega}<0$, and $L_{\omega \Omega}<0$. The magnitudes imply that when $\Omega=0$ the quit rate rises by about 1 percentage point for each onemonth rise in $\omega$ and the strike probability by about one-third of a point, so that if $\omega=8$ the quit rate rises by 50 percent and the strike rate more than doubles relative to the situation with no wage arrears. The estimated effect on the probability of legal penalties is also positive when $\Omega=0$, but again it declines as $\Omega$ increases. These costs of wage arrears are virtually vanishing in the observed range of behavior.

Concerning the results for other variables, union density, training provision, and the level of training costs are estimated to reduce the quit rate. The effect of union density on the strike probability is statistically insignificant, a result consistent with the assessment that Russian unions are weak (e.g., Gimpelson and Lippoldt, 2001). The fraction of cases where managers failed to pay assessed fines on time is estimated to have a negative impact on the probability of legal penalties, which we interpret as a reflection of the effectiveness of local legal institutions. The negative impact of the fraction of cases in which arrears were paid off may reflect the lower likelihood of penalties if the manager quickly pays wages after the Inspection Service brings a case. In any 
event, the results for all four components of costs strongly support the hypothesis of positive feedback loops, suggesting increasing returns to the use of wage arrears. ${ }^{29}$

\section{Estimating a Nonlinear Model of Wage Arrears Interactions}

Returning to the model in Section 3, we obtain the reaction function's second derivative:

$$
\frac{d^{2} \omega}{d \Omega^{2}}=\frac{C_{\omega \omega \Omega} \stackrel{(-)}{\omega \Omega}^{(-)} C_{\omega \Omega \Omega} C_{\omega \omega}^{(+)}}{C_{\omega \omega}{ }^{2}} \geq 0
$$

which may be positive as well as negative. Multiple equilibria require sign switching. Such a case, where the second derivative is initially positive and then turns negative after $\Omega$ exceeds the inflection point $\Omega_{l}$, is shown in Figure 1. To motivate this case more fully, we next consider a particular functional form for the cost function, one from which we derive an estimable reaction function that permits the possibility of multiple equilibria.

\subsection{A Particular Functional Form for Estimation}

Consider the following special form of the cost function:

$$
C=\omega \cdot\left(a \omega-b \Omega-c \Omega^{2}+d \Omega^{3}+e Z\right),
$$

which may generate multiple Nash equilibria, as we show below. We will again assume that the cost function satisfies the following conditions:

$$
\begin{aligned}
& C_{\omega}=a \omega+C / \omega>0, C_{\Omega}=\omega\left(-b-2 c \Omega+3 d \Omega^{2}\right)<0, \\
& C_{\omega \omega}=2 a>0, \quad C_{\omega \Omega}=-b-2 c \Omega+3 d \Omega^{2}=C_{\Omega}^{(-)} / \omega<0, \text { and } C_{\omega Z}=e>0 .
\end{aligned}
$$

Parameters $a$ and $e$ are positive by virtue of our earlier assumptions, but we also hypothesize that $c$ and $d$ are positive, while the sign of $b$ is ambiguous, for reasons that we discuss shortly. The firstorder condition of maximizing the objective function implies the equality of marginal return and marginal cost associated with wage arrears:

$$
\begin{aligned}
& \max _{\omega} \pi=r \omega-\omega\left(a \omega-b \Omega-c \Omega^{2}+d \Omega^{3}+e Z\right) \\
& r=2 a \omega-b \Omega-c \Omega^{2}+d \Omega^{3}+e Z .
\end{aligned}
$$

From the first order condition we can derive an estimable reaction function:

\footnotetext{
${ }^{29}$ The longer working paper version of this article contains discussion and empirical analysis of the possibility that wages and wage arrears are jointly determined. We find no statistically significant relationship and all point estimates on wage arrears in a hedonic wage function are negative, inconsistent with a tradeoff between the two variables.
} 


$$
\varpi=\left(b \Omega+c \Omega^{2}-d \Omega^{3}+r-e Z\right) / 2 a,
$$

where $\varpi$ is a cubic function of $\Omega$.

The reaction function exhibits positive feedback:

$$
\frac{\partial \varpi}{\partial \Omega}=\frac{b+2 c \Omega-3 d \Omega^{2}}{2 a}=-\frac{C_{\omega \Omega}^{(-)}}{2 a}>0 \text {. }
$$

But the sign of the second derivative is ambiguous:

$$
\frac{\partial^{2} \varpi}{\partial \Omega^{2}}=\frac{c-3 d \Omega}{a} \geq 0,
$$

depending on $c, d$, and $\Omega$. For fixed $c$ and $d>0$, the reaction function exhibits a cubic S-shape with inflection point at $\Omega_{i}=c / 3 d$. At lower levels of local labor market arrears $(\Omega<c / 3 d)$ the response function is convex, and at higher levels it is concave. We test these implications below.

\subsection{Equilibrium Wage Arrears}

In symmetric Nash equilibrium, where all firms in a local labor market face identical return and cost functions and where they take each other's actions as given, the level of firm wage arrears must be equal to the level of regional wage arrears $\left(\omega^{*}=\Omega^{*}\right)$, which implies

$$
-d \omega^{* 3}+c \omega^{* 2}+(b-2 a) \omega^{*}+r-e Z=0 .
$$

It is possible to solve this equation analytically for three equilibria in terms of $a, b, c, d, e, r$, and $Z$, but the equations describing the solutions are very long (several pages each). To simplify for illustrative purposes, we note that $r-e Z>0$ implies that even if no other firms in the region have wage arrears $(\Omega=0)$, the net return to wage arrears is still positive, implying $\omega>0$. Since most economies are characterized by regular payment of wage obligations, we normalize the results, assuming $r=e Z$, which implies simple analytical solutions for wage arrears equilibria:

$$
\begin{aligned}
& \omega_{1}^{*}=0 \\
& \omega_{2}^{*}=\frac{c-\sqrt{c^{2}+4 d(b-2 a)}}{2 d} \\
& \omega_{3}^{*}=\frac{c+\sqrt{c^{2}+4 d(b-2 a)}}{2 d} .
\end{aligned}
$$


The first equilibrium involves zero firm wage arrears at zero regional wage arrears, while positivity of the second requires $4 d(b-2 a)<0$, implying restrictions on $a$ and $b$ such that $b / 2 a<1$. $b$ may be positive or negative, although our hypotheses imply a generally positive slope.

We may label $\omega_{1}{ }^{*}$ the "contracts honored" or "punctual payment equilibrium," $\omega_{2}{ }^{*}$ the "critical mass" or "threshold equilibrium," and $\omega_{3}{ }^{*}$ the "contracts breached" or "wage arrears equilibrium." $\omega_{1}{ }^{*}$ and $\omega_{3}{ }^{*}$ are stable and $\omega_{2}{ }^{*}$ is unstable, as we show in our working paper (Earle and Sabirianova Peter, 2006). Figure 2 displays the symmetric Nash equilibria and the dynamics implied by the model. In the range where $\omega_{1}{ }^{*}<\Omega<\omega_{2}{ }^{*}$, a self-interested manager will choose $\omega$ $<\Omega$, so optimizing behavior by all managers will tend to drive down $\Omega$. Beyond $\omega_{2}{ }^{*}$, managerial behavior will tend to push up $\Omega$ until it reaches $\omega_{3}{ }^{*}$, the stable late payment equilibrium.

\subsection{Nonlinear Estimation Results}

Multiple equilibria may arise when the reaction function has an S-shape, so that at low levels of $\Omega, \partial^{2} \omega / \partial \Omega^{2}>0$, while at higher levels $\partial^{2} \omega / \partial \Omega^{2}<0$. The functional form of the manager's objective that we have employed as an example (Equation (13) above) suggests a cubic form for the reaction function, with alternating signs on the coefficients in the polynomial on $\Omega$. More specifically, we can test that the critical parameters $c$ and $d$ are both positive, while $b / 2 a<1$.

We therefore estimate the reaction function (14). Decomposing the $Z$ vector into observable and unobservable components leads directly to our estimating equation:

$$
\omega_{i}=\beta_{0}+\beta_{1} \Omega_{i}+\beta_{2} \Omega_{i}^{2}+\beta_{3} \Omega_{i}^{3}+\beta_{4} X_{i}+\beta_{5} Z_{i}^{\prime}+\xi_{i},
$$

where we use the subscript $i$ to index individual workers, and where $\beta_{1}=b / 2 a, \beta_{2}=c / 2 a, \beta_{3}=$ $d / 2 a, \beta_{4}=r^{\prime}\left(X_{i}\right) / 2 a$, and $\beta_{5}=-e / 2 a$. We have decomposed the vector of $Z$ controls to include a

constant, $\beta_{0}$, a vector of observable characteristics, $Z_{i}^{\prime}$, and a residual reflecting an unobserved component in the cost function, $\varepsilon_{i}$; thus, $Z_{i}=\beta_{0}+Z_{i}{ }^{\prime}+\varepsilon_{i}$, and $\xi_{i}=\varepsilon_{i} / 2 a$.

Because our analysis of the linear interactions model found similar results when we used instrumental variables based on public sector arrears, defense sector arrears, and national and federal region aggregations, we report estimates of Equation (19) without instrumenting, but to examine robustness we include both OLS and FE estimates in Table 7. In fact, as in the linear case, the inclusion of unobservable time-invariant effects at the district, firm, and worker level does 
little to alter the results, nor are the results much altered by the inclusion of a full set of interactions between federal regions and years. The results for $X$ and $Z$ variables are very similar to those in Table 3 and therefore are not displayed in Table 7.

Concerning the polynomial in $\Omega$, one of the less obvious predictions of the theoretical model, emerging from the discussion above, is that $b / 2 a=\beta_{1}<1$. This implication is satisfied by all the estimates in Table 7, and in all cases we can reject the hypothesis that $\beta_{l}=1$ at the 1 percent level. This is also a necessary condition for stability of the extreme equilibria. The signs of the estimates of $c$ and $d$ are also consistent with the theoretical model in all four estimated models, and they are statistically significantly different from zero.

The nonlinear estimation results continue to support the hypothesis of positive neighborhood effects over most of the relevant range. Only when district fixed effects are included is $\beta_{1}$ statistically significantly less than zero, and even in this case, the reaction function is estimated to have a positive slope for $\Omega>3.2$. In all cases, the point estimates of the coefficients imply an S-shaped reaction function.

\subsection{Simulating Symmetric Nash Equilibria}

Whether an S-shaped reaction function produces multiple equilibria depends on the magnitudes of the parameters. Using the estimated parameters of the empirical reaction function, we may simulate symmetric Nash equilibria and calculate the levels of arrears consistent with the two stable equilibria and with the unstable critical mass threshold.

Figure 3 graphs the estimated reaction function, taking the average of $\beta_{0}+\beta_{4} X_{i}{ }^{\prime}+\beta_{5} Z_{i}$ across all individuals in the sample, which then becomes the intercept for the plotted relationship. Under the assumption of symmetric Nash behavior in local labor markets, it is straightforward in principle to solve the estimated reaction functions for the set of average equilibria across regions. Figure 3 does this in the simplest way, by finding the intersection between the reaction function and a $45^{\circ}$ ray from the origin.

As is evident from the figure, the results suggest there are indeed multiple equilibria. The average punctual payment equilibrium in Russian regions involves less than one monthly wage debt, the critical mass equilibrium is 5.5 months, and the late payment equilibrium is 9.5 months. 
The estimates imply stability of the extreme equilibria $\omega_{1}^{*}$ and $\omega_{3}{ }^{*}$ and instability of the threshold $\omega_{2}{ }^{*}$. Thus, the data provide support for some of the model's crucial details as well as the most important predictions of positive feedback and multiple equilibria.

\subsection{Equilibrium Selection and Robustness}

If there are multiple equilibria in wage arrears, how do countries or regions get into the punctual payment or the late payment equilibrium? A natural candidate for selecting the equilibrium would be a large employer, one able to move the equilibrium from one side of the critical mass threshold to the other by setting a standard that other employers follow. In the Russian case, we argue that role was played by the state, which, as we have discussed, initiated late payments on a large scale by budgetary sequestration to reduce the fiscal deficit. It is notable that the share of employment accounted for by the public sector was actually growing through most of this standard-setting period. ${ }^{30}$

How robust is the late payment equilibrium? For instance, while our analysis has focused on symmetric Nash equilibria, what prevents some firm, say a new entrant, from violating the latepayment norm by offering workers a lower wage, but one paid regularly on time? Our model shows that identical firms will not defect from the late payment equilibrium, but in practice there is likely to be heterogeneity, particularly in the case of new start-ups. Firms with profitable opportunities seeking to hire new employees may try to build a reputation for punctual payment if workers care about this characteristic of their jobs.

While such a process may sometimes occur in a number of regions of Russia, in order to explain why it does not unravel the late payment equilibrium in regions with persistently high arrears, we must call upon other aspects of the Russian environment: the severe recession, the limited role of entry, and the continual instability and illiquidity. The large fall in output and consumption has reduced the profitability of entry, and the continual instability has made it difficult for firms to establish reputations. We can imagine a signaling game in which there are two types of firms: in one type, where prospects are poor, managers simply try to steal wages; in

\footnotetext{
${ }^{30}$ According to OECD (1997), employment in public administration grew steadily from 663,000 in 1990 to $1,087,000$ in 1995 , or from 0.88 to 1.64 percent of total employment.
} 
the other, which has profitable projects, managers try to pay workers and build a reliable reputation in order to increase effort and reduce turnover. But the type of firm is unobservable to workers, and all managers can announce (as they have done) their most sincere intentions to pay wages "as soon as the firm has money." In this situation, the ability of the second type of managers to distinguish themselves from the first type amounts to the possibility for existence of a separating equilibrium. If economic instability is so great that occasional shocks hit every firm with some probability, rendering them temporarily unable to pay, then firms cannot build a reputation and workers may not be able to distinguish the firm types in practice. This analysis is outside our formal model, and it is difficult to verify empirically, but it does explain why a late payment equilibrium may be robust even when new entry and firm heterogeneity are permitted.

\section{Conclusion}

This paper has developed and tested several key features of a model of local labor market interactions in employer decisions to violate wage contracts. Our model provides a framework for understanding how such interactions may arise through the relationship between the costs to employers of using arrears and the extent of arrears in the local labor market environment. It also provides some guidance for empirical estimation of the reaction function and of the feedback loops that may support a timely or late wage payment practice. Under certain circumstances, the model also suggests the possibility of multiple equilibria.

Our empirical analysis provides strong evidence of positive feedback in the manager's choice of wage arrears from the behavior of other firms operating in the same local labor market. Rational managers do indeed appear to take into account the wage arrears behavior of neighboring employers when choosing their own strategies. This result for the nonpublic sector of the Russian economy is robust to the inclusion of fixed effects at the level of the worker, the firm, and the local labor market, and to the use of instrumental variables associated with the exogenous determination of arrears in the public sector.

Furthermore, the data provide strong support for the existence of several feedback loops. We find that higher wage arrears in the local labor market attenuate the positive impact of arrears on the worker's quit probability and the firm's quit rate. Higher local arrears also reduce the 
negative impact of a worker's arrears on measures of effort and work hours. They reduce the positive impact of arrears on the strike probability, and they reduce the impact of the level of a firm's arrears on the probability that a legal penalty will be assessed.

The final empirical results concern the nonlinear reaction function and the possibility of multiple equilibria in wage arrears. Our estimates of a cubic reaction function, derived from a particular functional form for the costs of arrears, imply a clear S-shape. The magnitudes of the parameters imply that the average Russian region may indeed face multiple equilibria. The estimates imply a threshold equilibrium of about 5.5 monthly wages and a late payment equilibrium of 9.5. We hasten to add that these results are merely illustrative of the method that can be used for addressing this issue, but we believe they are highly suggestive of the existence of multiple equilibria in the practice of wage contract violations.

If the practice of contract violation exhibits multiple equilibria, what are the welfare characteristics of the contract violation versus the punctual payment equilibrium? Notwithstanding injunctions against wage delays reaching back to Moses, some observers praise wage arrears as a way of achieving wage flexibility and low unemployment in Russia (Layard and Richter, 1995; OECD, 1997). We would argue on the contrary that wage arrears are far from a socially efficient mechanism for bringing about a given real wage cut: the reduction in utility is greater because of the uncertainty concerning the timing and probability of eventual payment.

It seems to us, however, that the major consideration in a normative evaluation of arrears stems from the importance of wage contracts to most individuals. The violation of those contracts reduces confidence in other labor and nonlabor contracts into which the individual might enter, and thus may undermine the development of contract enforcement and rule of law. North (1990) and others have argued these are critical institutions in promoting impersonal exchange, potentially accounting for much of the variation across countries in economic growth and performance. Our analysis provides a case study of the lock-in of an institutional practice that is inimical to these institutions and thus to the development of a healthy market economy. 


\section{References}

Akerlof, George A., "A Theory of Social Custom, of Which Unemployment May be One Consequence.” Quarterly Journal of Economics, 94(4): 749-775, June 1980.

Alfandari, Gilles, and Mark E. Schaffer, “Arrears' in the Russian Enterprise Sector,” in Simon Commander, Qimaio Fan, and Mark E. Schaffer, eds., Enterprise Restructuring and Economic Policy in Russia. Washington, D.C.: The World Bank, 1996.

Andrienko, Yury, and Sergei Guriev, "Determinants of Interregional Mobility in Russia: Evidence from Panel Data.” Economics of Transition, 12(1): 1-27, March 2004.

Aoki, Masa, Toward a Comparative Institutional Analysis. Cambridge, MA: MIT Press, 2001.

Bardhan, Pranab, “Corruption and Development: A Review of Issues.” Journal of Economic Literature, 35(3): 1320-1346, September 1997.

Bertrand, Marianne, Erzo F.P. Luttmer, and Sendhil Mullainathan, "Network Effects and Welfare Cultures.” Quarterly Journal of Economics, 155(3): 1019-1055, August 2000.

Blume, Lawrence E., and Steven N. Durlauf, "The Interactions-Based Approach to Socioeconomic Behavior," in Steven N. Durlauf and H. Peyton Young, eds., Social Dynamics, pp. 15-44. Washington, DC: Brookings Institution Press, 2001.

Brock, William A., and Steven N. Durlauf, “Interactions-Based Models,” in James J. Heckman and Edward Leamer, eds., Handbook of Econometrics, Vol. 5, pp. 3297-3380. Amsterdam: Elsevier Science Publishers, 2001.

Brown, J. David, and John S. Earle, "The Reallocation of Workers and Jobs in Russian Industry: New Evidence on Measures and Determinants.” Economics of Transition, 11(2): 221-252, June 2003.

Bulow, Jeremy, John Geanakoplos, and Paul Klemperer, "Multimarket Oligopoly: Strategic Substitutes and Complements.” Journal of Political Economy, 93(3): 488-511, June 1985.

Desai, Padma, and Todd Idson, Work without Wages: Russia's Nonpayment Crisis. Cambridge, MA: MIT Press, 2000.

Dewatripont, Mathias, and Gerard Roland, "Transition as a Process of Large-Scale Institutional Change.” Economics of Transition, 4(1): 1-30, May 1996.

Earle, John S., and Klara Sabirianova, "How Late to Pay? Understanding Wage Arrears in Russia." Journal of Labor Economics, 20(3): 661-707, July 2002.

Earle, John S., and Klara Sabirianova Peter, "Complementarity and Custom in Wage Contract Violation,” Upjohn Institute Staff Working Paper, No. 129, 2006.

Evans, William, Wallace Oates, and Robert Schwab, "Measuring Peer Group Effects: A Study of Teenage Behavior.” Journal of Political Economy, 100(5): 966-991.

Gimpelson, Vladimir, “The Politics of Labour Market Adjustment: The Case of Russia.” Collegium Budapest (Budapest) Discussion Paper No. 54, November 1998.

Gimpelson, Vladimir, and Douglas Lippoldt, The Russian Labor Market: Between Transition and Turmoil. Lanham, MD/Oxford, UK: Rowman and Littlefield, 2001.

Goskomstat, Overdue Wage Payments on January 1, 1999 (Statistical Bulletin). Moscow: Goskomstat of Russia, 1999. 
Gregory, Paul R., and Aleksei Tikhonov, "Central Planning and Unintended Consequences: Creating the Soviet Financial System, 1930-1939.” Journal of Economic History, 60(4): 10171040, December 2000.

Greif, Avner, and Eugene Kandel, "Contract Enforcement Institutions: Historical Perspective and Current Status in Russia," in Edward Lazear, ed., Economic Transition in Eastern Europe and Russia: Realities of Reform. Stanford: Hoover Institution Press, 1995.

Greif, Avner, Paul Milgrom, and Barry R. Weingast, "Coordination, Commitment, and Enforcement: The Case of the Merchant Guild." Journal of Political Economy, 102(4): 745-776, August 1994.

Hadfield, Gillian K., "Contract Law is Not Enough: The Many Legal Institutions that Support Contractual Commitments," in Claude Menard and Mary Shirley, eds., Handbook of New Institutional Economics. Boston: Kluwer, 2004.

Institute for the Economy in Transition, Russian Economy in 1993: Trends and Prospects. Moscow: Institute for the Economy in Transition, 1994.

Javeline, Deborah, Protest and the Politics of Blame: The Russian Response to Unpaid Wages. Ann Arbor: University of Michigan Press, 2003.

Johnson, Simon, Daniel Kaufmann, and Andrei Shleifer, "The Unofficial Economy in Transition.” Brookings Papers on Economic Activity, 2, 159-239, 1997.

Layard, Richard, and Andrea Richter, "How Much Unemployment is Needed for Restructuring: The Russian Experience.” Economics of Transition, 3(1): 35-58, March 1995.

Lehmann, Hartmut, Jonathan Wadsworth, and Alessandro Acquisti, "Grime and Punishment: Job Insecurity and Wage Arrears in the Russian Federation." Journal of Comparative Economics, 27(4): 595-617, December 1999.

Manski, Charles F., "Identification of Endogenous Social Effects: The Reflection Problem." Review of Economic Studies, 60(3): 531-542, July 1993.

Milgrom, Paul R., Douglass North, and Barry R. Weingast, "The Role of Institutions in the Revival of Trade: The Medieval Law Merchant, Private Judges, and the Champagne Fairs.” Economics and Politics, 2(1): 1-23, March 1990.

Milgrom, Paul, and John Roberts, "Rationalizability, Learning, and Equilibrium in Games with Strategic Complementarities.” Econometrica, 57(6): 1255-1277, November 1990.

Mitchneck, Beth, and David A. Plane, "Migration and the Quasi-Labor Market in Russia." International Regional Science Review, 18(3): 267-288, 1995.

Moffitt, Robert A., "Policy Interventions, Low-Level Equilibria, and Social Interactions," in Steven N. Durlauf and H. Peyton Young, eds., Social Dynamics, pp. 45-82. Washington, D.C.: Brookings Institution Press, 2001.

Murrell, Peter, "Evolution in Economics and in the Economic Reform of the Centrally Planned Economies," in C.C. Clague and G. Rausser, eds., The Emergence of Market Economies in Eastern Europe, pp. 35-53. Cambridge, MA, and Oxford: Blackwell, 1992.

North, Douglass C., Institutions, Institutional Change, and Economic Performance. New York: Cambridge University Press, 1990.

OECD Economic Surveys 1997-1998: The Russian Federation. Paris: OECD, 1997. 
Radio Free Europe/Radio Liberty (RFE/RL) Newsline, “Wage Arrears Swell.” Vol. 8(81), pt. 2, April 30, 2004.

Sah, Raaj K., “Social Osmosis and Patterns of Crime.” Journal of Political Economy, 99(6): 12721295, December 1991.

U.S. Department of Labor, Employment Standards Administration, Wage and Hour Division, “FairPay Enforcement Statistics for 2003,” 2003, http://www.dol.gov/esa/regs/compliance/whd/fairpay/statistics_2003.htm.

Young, H. Peyton, “The Evolution of Conventions.” Econometrica, 61(1): 57-84, January 1993.

Young, H. Peyton, and Mary A. Burke, "Competition and Custom in Economic Contracts: A Case Study of Illinois Agriculture.” American Economic Review, 91(3): 559-573, June 2001. 
Table 1: Magnitude of Wage Arrears, Worker Data

\begin{tabular}{|c|c|c|c|c|c|}
\hline & 1994 & 1995 & 1996 & 1998 & 2000 \\
\hline \multicolumn{6}{|l|}{$\operatorname{Mean}\left(\omega_{i t}\right)$} \\
\hline All sectors & 1.10 & 1.11 & 1.92 & 3.00 & 1.14 \\
\hline Public sector & 0.82 & 0.88 & 1.80 & 2.93 & 0.97 \\
\hline Defense sector & 1.42 & 1.15 & 2.75 & 4.21 & 1.35 \\
\hline $\operatorname{Mean}\left(\omega_{i t} \mid \omega_{i t}>0\right)$ & 2.75 & 2.73 & 3.27 & 4.82 & 4.24 \\
\hline \multicolumn{6}{|c|}{ Unconditional distribution $\left(\omega_{i t}\right)$} \\
\hline$\omega_{i t}=0$ month & 0.603 & 0.593 & 0.415 & 0.379 & 0.731 \\
\hline$=1$ month & 0.149 & 0.156 & 0.149 & 0.122 & 0.111 \\
\hline$=2-3$ months & 0.164 & 0.170 & 0.250 & 0.219 & 0.085 \\
\hline$=4-6$ months & 0.055 & 0.055 & 0.134 & 0.163 & 0.032 \\
\hline$=7-9$ months & 0.014 & 0.007 & 0.025 & 0.046 & 0.007 \\
\hline$>9$ months & 0.016 & 0.019 & 0.028 & 0.072 & 0.034 \\
\hline \multicolumn{6}{|c|}{$\Omega_{j t}$ in selected districts } \\
\hline “A” & 0.417 & 0.478 & 1.167 & 1.080 & 0.407 \\
\hline "B” & 0.627 & 0.480 & 0.593 & 1.256 & 0.137 \\
\hline “C” & 2.236 & 2.274 & 3.574 & 4.301 & 1.408 \\
\hline “D” & 4.119 & 6.581 & 6.175 & 11.690 & 9.898 \\
\hline Observations & 4667 & 4310 & 4050 & 3781 & 4000 \\
\hline
\end{tabular}

Notes: $\omega_{i t}=$ number of monthly wages reported overdue by an employee-respondent $i$ in year $t ; \Omega_{j t}=$ average number of monthly wages owed in the rest of the firm's local labor market. Sample consists of all employee-respondents in the RLMS. Districts are indicated as " $A$ " through " $D$ " because the RLMS data confidentiality agreement precludes the release of district names. 
Table 2: Characteristics of the Worker and Firm Samples

\begin{tabular}{|c|c|c|c|}
\hline Worker Sample & Mean & Firm Sample & Mean \\
\hline Public sector & 0.360 & $\omega_{i t}$ (number of monthly & 1.175 \\
\hline Defense sector & 0.053 & wages overdue) & $(2.375)$ \\
\hline$\Omega_{j t}$ (local arrears) & $\begin{array}{c}1.606 \\
(1.460)\end{array}$ & $\Omega_{j t}$ (local arrears) & $\begin{array}{c}1.146 \\
(1.321)\end{array}$ \\
\hline Male & 0.478 & Strikes (dummy) & 0.019 \\
\hline Schooling (years) & $\begin{array}{l}11.823 \\
(2.542)\end{array}$ & Quit rate (quits/employment) & $\begin{array}{c}0.169 \\
(0.169)\end{array}$ \\
\hline Age (years) & $\begin{array}{c}39.135 \\
(11.817)\end{array}$ & $\begin{array}{l}\text { Legal penalties (dummy) } \\
\text { Union density (\% members) }\end{array}$ & 0.010 \\
\hline Tenure (years) & $\begin{array}{l}8.345 \\
(9.141)\end{array}$ & $\begin{array}{l}0-9 \% \\
10-59 \%\end{array}$ & $\begin{array}{l}0.086 \\
0.095\end{array}$ \\
\hline Employee owns & & $60-79 \%$ & 0.088 \\
\hline No shares & 0.812 & $80-89 \%$ & 0.087 \\
\hline$<1 \%$ & 0.104 & $90-99 \%$ & 0.275 \\
\hline$\geq 1 \%$ & 0.036 & $100 \%$ & 0.369 \\
\hline No information & 0.048 & Firm fringe benefits & \\
\hline Hourly wage rate (rubles) & $\begin{array}{c}14.058 \\
(21.016)\end{array}$ & $\begin{array}{l}\text { Training } \\
\text { Kindergartens }\end{array}$ & $\begin{array}{l}0.647 \\
0.433\end{array}$ \\
\hline Family income (thous. rubles) & $\begin{array}{c}0.966 \\
(1.788)\end{array}$ & $\begin{array}{l}\text { Housing } \\
\text { Training costs (days) /100 }\end{array}$ & $\begin{array}{c}0.382 \\
82.022\end{array}$ \\
\hline Industry & & & $(92.850)$ \\
\hline Mining & 0.023 & Industry & \\
\hline Machine building & 0.109 & Energy \& fuel & 0.088 \\
\hline Light and food & 0.050 & Metallurgy \& chemicals & 0.081 \\
\hline Other manufacturing & 0.101 & Machine building & 0.318 \\
\hline Agriculture/forestry & 0.103 & Wood and building materials & 0.105 \\
\hline Transportation & 0.078 & Light & 0.089 \\
\hline Construction & 0.071 & Food & 0.135 \\
\hline Private services & 0.140 & Other & 0.060 \\
\hline Public services & 0.326 & Agriculture & 0.123 \\
\hline Monthly hours of work & $\begin{array}{l}147.940 \\
(73.898)\end{array}$ & $\begin{array}{l}\text { Type of location } \\
\text { Moscow and St. Petersburg }\end{array}$ & 0.105 \\
\hline Desire to switch jobs & 0.379 & Regional capital city & 0.360 \\
\hline Quit in two years & 0.291 & Other city & 0.342 \\
\hline Occupation & & Non-city & 0.194 \\
\hline Managers and professionals & 0.193 & Legal Environment in region & \\
\hline Technicians & 0.176 & Fraction of cases when managers & 0.098 \\
\hline Clerks and service workers & 0.166 & fail to pay assessed fines on time & $(0.085)$ \\
\hline Craft workers & 0.176 & Fraction of cases where arrears were & 0.216 \\
\hline Operators and assemblers & 0.181 & paid off after violation was & $(0.158)$ \\
\hline Unskilled workers and army & 0.108 & discovered & \\
\hline
\end{tabular}

Notes: Observations in the worker sample=20106, except for non-zero hourly wage rate (17285), hours (19248), desire to switch jobs (19548), and quits (9441). The worker sample consists of all employee-respondents with nonmissing values on wage arrears, schooling, age, tenure, occupation, and industry. Observations in the firm sample=4061, except for quit rate (2611) and legal penalties (3675). Sample consists of industrial and agricultural firms with nonmissing values on wage arrears, union density, and fringe benefits in 1991-1999. Standard deviations are shown in parentheses. The quit rate is ratio of number quitting to average employment. 
Table 3: Linear Reaction Function, Nonpublic Sector

\begin{tabular}{|c|c|c|c|c|}
\hline & OLS & District FE & Firm FE & $\begin{array}{c}\text { Firm- } \\
\text { Worker FE } \\
\end{array}$ \\
\hline \multicolumn{5}{|c|}{ Panel $A$} \\
\hline$\Omega_{j t}$ (local arrears) & $\begin{array}{l}0.715^{* * *} \\
(0.052)\end{array}$ & $\begin{array}{l}0.385^{* * *} \\
(0.097)\end{array}$ & $\begin{array}{l}0.747 * * * \\
(0.086)\end{array}$ & $\begin{array}{l}0.819 * * * \\
(0.130)\end{array}$ \\
\hline Male & $\begin{array}{l}0.400^{* * * *} \\
(0.101)\end{array}$ & $\begin{array}{l}0.398^{* * * *} \\
(0.097)\end{array}$ & $\begin{array}{l}0.349 * * * \\
(0.117)\end{array}$ & $\ldots$ \\
\hline Schooling (years) & $\begin{array}{c}0.013 \\
(0.022)\end{array}$ & $\begin{array}{c}0.008 \\
(0.021)\end{array}$ & $\begin{array}{l}-0.014 \\
(0.027)\end{array}$ & $\begin{array}{l}-0.025 \\
(0.030)\end{array}$ \\
\hline Age (years) & $\begin{array}{c}0.002 \\
(0.003)\end{array}$ & $\begin{array}{c}0.001 \\
(0.003)\end{array}$ & $\begin{array}{c}0.010^{*} \\
(0.005)\end{array}$ & $\ldots$ \\
\hline Tenure (years) & $\begin{array}{l}0.024^{* * * *} \\
(0.004)\end{array}$ & $\begin{array}{l}0.027^{* * * *} \\
(0.005)\end{array}$ & $\begin{array}{l}0.023^{* * *} \\
(0.006)\end{array}$ & $\begin{array}{l}0.025^{* *} \\
(0.011)\end{array}$ \\
\hline Log of hourly wage rate & $\begin{array}{l}-0.375^{* * * *} \\
(0.045)\end{array}$ & $\begin{array}{l}-0.461^{* * *} \\
(0.053)\end{array}$ & $\begin{array}{l}-0.384^{* * * *} \\
(0.068)\end{array}$ & $\begin{array}{l}-0.349 * * * \\
(0.086)\end{array}$ \\
\hline Log of family income & $\begin{array}{l}-0.030 \\
(0.035)\end{array}$ & $\begin{array}{l}-0.076^{* *} \\
(0.031)\end{array}$ & $\begin{array}{l}-0.062 \\
(0.038)\end{array}$ & $\begin{array}{l}-0.033 \\
(0.067)\end{array}$ \\
\hline \multicolumn{5}{|c|}{ Employee owns (omitted: No shares) } \\
\hline$<1 \%$ & $\begin{array}{l}0.337 * * * \\
(0.106)\end{array}$ & $\begin{array}{l}0.371^{* * *} \\
(0.100)\end{array}$ & $\begin{array}{l}0.226^{* *} \\
(0.110)\end{array}$ & $\begin{array}{c}0.273 \\
(0.174)\end{array}$ \\
\hline$\geq 1 \%$ & $\begin{array}{c}0.221 \\
(0.152)\end{array}$ & $\begin{array}{c}0.221^{*} \\
(0.132)\end{array}$ & $\begin{array}{c}0.105 \\
(0.264)\end{array}$ & $\begin{array}{c}0.108 \\
(0.291)\end{array}$ \\
\hline$F$-test for occupation effects & $2.05^{*}$ & $2.27 * *$ & 0.77 & 0.34 \\
\hline$F$-test for industry effects & $9.60 * * *$ & $11.74 * * *$ & 1.23 & 0.86 \\
\hline$F$-test for year effects & $2.62 * *$ & $5.81^{* * *}$ & $2.62 * *$ & $3.09 * *$ \\
\hline F-test for district effects & $\ldots$ & $1992.01^{* * *}$ & $\ldots$ & $\ldots$ \\
\hline$R^{2}\left(R^{2}\right.$-within for FE estimates) & 0.256 & 0.280 & 0.126 & 0.151 \\
\hline \multicolumn{5}{|c|}{ Panel B } \\
\hline $\begin{array}{l}\Omega_{j t} \text { (local arrears) } \\
R^{2} \text { ( } R^{2} \text {-within for FE estimates) }\end{array}$ & $\begin{array}{l}0.634 * * * \\
(0.051) \\
0.262 \\
\end{array}$ & $\begin{array}{c}0.227^{*} \\
(0.122) \\
0.155\end{array}$ & $\begin{array}{l}0.609 * * * \\
(0.108) \\
0.136\end{array}$ & $\begin{array}{l}0.818^{* * *} \\
(0.130) \\
0.153\end{array}$ \\
\hline
\end{tabular}

Notes: Observations=12850 employee-respondents in the nonpublic sector. Robust standard errors in parentheses are adjusted for clustering within local areas; * significant at $10 \%$; ** significant at $5 \%$; *** significant at $1 \%$. The constant term, 9 occupation dummies, 9 industry dummies, 5 year dummies, and 3 dummies for missing values of log of wages, log of family income, and employee ownership are included but not shown in Panel A. The specification in Panel B includes the same set of covariates as in Panel A as well as the full interaction between the federal region dummies and year dummies. 
Table 4: Linear Reaction Function with Instrumental Variables, Nonpublic Sector

\begin{tabular}{|c|c|c|c|c|c|c|c|c|c|c|}
\hline & \multicolumn{5}{|c|}{ District FE } & \multicolumn{5}{|c|}{ Firm FE } \\
\hline & 1 & 2 & 3 & 4 & 5 & 1 & 2 & 3 & 4 & 5 \\
\hline \multicolumn{11}{|c|}{ Second stage results for local arrears } \\
\hline$\Omega_{j t}$ (local arrears) & $\begin{array}{l}0.702 * * * \\
(0.134)\end{array}$ & $\begin{array}{l}0.607 * * * \\
(0.153)\end{array}$ & $\begin{array}{l}0.862 * * * \\
(0.297)\end{array}$ & $\begin{array}{c}0.778 * \\
(0.410)\end{array}$ & $\begin{array}{c}0.730^{*} \\
(0.400)\end{array}$ & $\begin{array}{l}0.881 * * * \\
(0.194)\end{array}$ & $\begin{array}{l}0.696 * * * \\
(0.194)\end{array}$ & $\begin{array}{l}0.957 * * \\
(0.379)\end{array}$ & $\begin{array}{c}0.852 * \\
(0.456)\end{array}$ & $\begin{array}{c}0.773^{*} \\
(0.445)\end{array}$ \\
\hline $\begin{array}{l}n_{p j t} \text { (local share of public } \\
\text { sector employees) }\end{array}$ & $\ldots$ & $\ldots$ & $\begin{array}{c}1.858 \\
(1.142)\end{array}$ & $\begin{array}{c}2.003 \\
(1.306)\end{array}$ & $\begin{array}{l}2.078 * \\
(1.249)\end{array}$ & $\ldots$ & $\ldots$ & $\begin{array}{l}3.444^{* *} \\
(1.516)\end{array}$ & $\begin{array}{l}3.613 * * \\
(1.617)\end{array}$ & $\begin{array}{l}3.710^{* *} \\
(1.609)\end{array}$ \\
\hline Hansen $J$ statistic & 4.182 & 4.041 & 1.179 & $\ldots$ & 0.028 & 4.125 & 1.723 & 1.504 & $\ldots$ & 0.064 \\
\hline Hansen $p$-value & 0.041 & 0.044 & 0.278 & $\ldots$ & 0.866 & 0.042 & 0.189 & 0.220 & $\ldots$ & 0.800 \\
\hline$R^{2}$-within second stage & 0.146 & 0.134 & 0.134 & 0.137 & 0.138 & 0.125 & 0.123 & 0.126 & 0.128 & 0.128 \\
\hline & 12850 & 8931 & 12850 & 12850 & 12850 & 12850 & 8931 & 12850 & 12850 & 12850 \\
\hline \multicolumn{11}{|c|}{ First stage results } \\
\hline$n_{p j t}$ & $\begin{array}{l}1.253^{* *} \\
(0.531)\end{array}$ & $\begin{array}{c}2.25^{*} \\
(1.192)\end{array}$ & $\begin{array}{l}2.786 * * * \\
(0.984)\end{array}$ & $\begin{array}{l}2.847 * * * \\
(1.066)\end{array}$ & $\begin{array}{l}2.965 * * * \\
(1.028)\end{array}$ & $\begin{array}{l}1.120^{*} \\
(0.590\end{array}$ & $\begin{array}{l}2.436 * * \\
(1.186)\end{array}$ & $\begin{array}{l}2.515^{* *} \\
(1.027)\end{array}$ & $\begin{array}{l}2.586^{* *} \\
(1.099)\end{array}$ & $\begin{array}{l}2.729 * * \\
(1.057)\end{array}$ \\
\hline$\Omega_{p j t}$ & $\begin{array}{l}0.661^{* * *} \\
(0.075)\end{array}$ & $\begin{array}{l}0.063 * * * \\
(0.019)\end{array}$ & $\ldots$ & $\ldots$ & $\ldots$ & $\begin{array}{l}0.666 * * * \\
(0.081)\end{array}$ & $\begin{array}{l}0.063^{* * *} \\
(0.019)\end{array}$ & $\ldots$ & $\ldots$ & $\ldots$ \\
\hline$\Omega_{p t}$ & .. & $\ldots$ & $\begin{array}{l}0.564^{* *} \\
(0.221)\end{array}$ & $\ldots$ & $\cdots$ & $\ldots$ & $\ldots$ & $\begin{array}{l}0.552^{* *} \\
(0.222)\end{array}$ & $\ldots$ & $\ldots$ \\
\hline$\Omega_{p t} \cdot n_{p j t}$ & $\ldots$ & $\ldots$ & $\begin{array}{l}-0.971^{*} \\
(0.532)\end{array}$ & $\begin{array}{l}-1.064^{*} \\
(0.635)\end{array}$ & $\begin{array}{l}-4.427^{*} \\
(2.525)\end{array}$ & $\ldots$ & $\ldots$ & $\begin{array}{l}-0.942 * \\
(0.547)\end{array}$ & $\begin{array}{c}-1.055^{*} \\
(0.643)\end{array}$ & $\begin{array}{l}-4.453^{*} \\
(2.583)\end{array}$ \\
\hline$\Omega_{p t} \cdot n_{p j t}^{2}$ & $\ldots$ & $\ldots$ & $\ldots$ & $\ldots$ & $\begin{array}{c}4.529 \\
(3.209)\end{array}$ & $\ldots$ & $\cdots$ & $\ldots$ & $\ldots$ & $\begin{array}{c}4.636 \\
(3.250)\end{array}$ \\
\hline$F$-test of excluded IVs & $42.561 * * *$ & $6.688 * * *$ & $3.331 * *$ & $2.811^{*}$ & $2.536 *$ & $35.019 * * *$ & $6.746 * * *$ & $3.195 * *$ & $2.69 *$ & $2.3^{*}$ \\
\hline$R^{2}$ first stage & 0.742 & 0.702 & 0.622 & 0.615 & 0.618 & 0.748 & 0.713 & 0.630 & 0.624 & 0.627 \\
\hline
\end{tabular}

Notes: Robust standard errors in parentheses are adjusted for clustering within local areas; * significant at $10 \%$; ** significant at 5\%; *** significant at $1 \%$. All specifications in Table 4 include the same set of covariates as in Table $3 . n_{p j t}$ is the local share of public sector employees in (1) and (3)-(5) and the local share of defense sector employees in (2); $\Omega_{p j t}$ is average wage arrears of the public sector employees in the local district in (1) and average wage arrears of defense workers in the local district in (2); $\Omega_{p t}$ is federal region wage arrears in the public sector outside of a given local area in (3), and national public sector wage arrears in (4)-(5). The public sector consists of municipal utilities, public services such as health care, education, and government, and defense industries. The defense sector includes employees in defense manufacturing and army. 
Table 5: Costs of Wage Arrears, Results from Worker Data

\begin{tabular}{l|ccc}
\hline & $\begin{array}{c}\text { Desire to } \\
\text { Switch Jobs } \\
\text { (Probit, dF/dX) }\end{array}$ & $\begin{array}{c}\text { Hours of Work } \\
\text { (Tobit) }\end{array}$ & $\begin{array}{c}\text { Quit in } \\
\text { Two Years } \\
\text { (Probit, dF/dX) }\end{array}$ \\
\hline$\omega_{i t}$ (monthly wages overdue) & $0.022^{* * *}$ & $-1.870^{* * *}$ & $0.008^{* * *}$ \\
$\Omega_{j t}$ (local arrears) & $(0.002)$ & $(0.260)$ & $(0.003)$ \\
$\omega_{i t}{ }^{*} \Omega_{j t}$ & -0.003 & -1.249 & -0.003 \\
& $(0.006)$ & $(0.889)$ & $(0.009)$ \\
Male & $-0.002^{* * *}$ & $0.210^{* * *}$ & $-0.001^{*}$ \\
& $(0.000)$ & $(0.052)$ & $(0.001)$ \\
Schooling (years) & $-0.017^{*}$ & $31.135^{* * *}$ & $0.066^{* * *}$ \\
Age (years) & $(0.009)$ & $(1.223)$ & $(0.012)$ \\
Tenure (years) & $0.012^{* * *}$ & $0.896^{* * *}$ & $-0.010^{* * *}$ \\
Log of hourly wage rate & $(0.002)$ & $(0.268)$ & $(0.003)$ \\
Log of family income & $-0.008^{* * *}$ & $0.290^{* * *}$ & $0.002^{* * *}$ \\
& $(0.000)$ & $(0.050)$ & $(0.000)$ \\
Employee owns (omitted: No shares) & $-0.007^{* * *}$ & $-0.199^{* * *}$ & $-0.007 * * *$ \\
$<1 \%$ & $(0.000)$ & $(0.065)$ & $(0.001)$ \\
& $-0.072^{* * *}$ & $-17.947 * * *$ & $-0.027 * * *$ \\
$\geq 1 \%$ & $(0.005)$ & $(0.677)$ & $(0.007)$ \\
& $-0.007^{*}$ & -0.812 & 0.008 \\
Observations & $(0.004)$ & $(0.600)$ & $(0.006)$ \\
Pseudo $R^{2}$ & & & $-0.042^{* * *}$ \\
& 0.007 & -0.073 & $(0.016)$ \\
& $(0.013)$ & $(1.759)$ & 0.001 \\
& $-0.088^{* * *}$ & $18.958^{* * *}$ & $(0.026)$ \\
\hline
\end{tabular}

Notes: Sample consists of all employee-respondents in the RLMS. Robust standard errors in parentheses; * significant at 10\%; ** significant at 5\%; *** significant at $1 \%$. The constant term, 9 occupation dummies, 9 industry dummies, 52 district dummies, 5 year dummies, and 3 dummies for missing values of log of wages, log of family income, and employee ownership are included but not shown here. 
Table 6: Costs of Wage Arrears, Results from Firm Data

\begin{tabular}{|c|c|c|c|}
\hline & $\begin{array}{c}\text { Quit Rate } \\
\text { (OLS) }\end{array}$ & $\begin{array}{c}\text { Strikes } \\
\text { (Probit, dF/dX) }\end{array}$ & $\begin{array}{l}\text { Legal Penalties } \\
\text { (Probit, dF/dX) }\end{array}$ \\
\hline $\begin{array}{l}\omega_{i t} \text { (number of monthly wages } \\
\text { overdue) }\end{array}$ & $\begin{array}{l}0.010^{* * * *} \\
(0.002)\end{array}$ & $\begin{array}{l}0.003^{* * *} \\
(0.001)\end{array}$ & $\begin{array}{l}0.0006 * * \\
(0.0003)\end{array}$ \\
\hline$\Omega_{j t}$ (local arrears) & $\begin{array}{l}-0.001 \\
(0.004)\end{array}$ & $\begin{array}{l}0.002^{* *} \\
(0.001)\end{array}$ & $\begin{array}{c}0.0004 \\
(0.0003)\end{array}$ \\
\hline$\omega_{i t} * \Omega_{j t} / 100$ & $\begin{array}{l}-0.168 * * \\
(0.076)\end{array}$ & $\begin{array}{l}-0.060^{* * *} \\
(0.020)\end{array}$ & $\begin{array}{l}-0.0134^{* *} \\
(0.0067)\end{array}$ \\
\hline \multicolumn{4}{|l|}{ Union density (100\% is omitted) } \\
\hline $0-9 \%$ & $\begin{array}{l}0.047 * * \\
(0.023)\end{array}$ & $\begin{array}{l}-0.001 \\
(0.003)\end{array}$ & $\ldots$ \\
\hline $10-59 \%$ & $\begin{array}{l}0.024 * * \\
(0.012)\end{array}$ & $\begin{array}{c}0.002 \\
(0.004)\end{array}$ & $\ldots$ \\
\hline $60-79 \%$ & $\begin{array}{l}-0.009 \\
(0.011)\end{array}$ & $\begin{array}{c}0.009 \\
(0.006)\end{array}$ & $\ldots$ \\
\hline $80-89 \%$ & $\begin{array}{l}-0.000 \\
(0.011)\end{array}$ & $\begin{array}{l}0.004 \\
(0.004)\end{array}$ & $\ldots$ \\
\hline $90-100 \%$ & $\begin{array}{c}0.002 \\
(0.006)\end{array}$ & $\begin{array}{c}0.000 \\
(0.003)\end{array}$ & $\ldots$ \\
\hline \multicolumn{4}{|l|}{ Fringe benefits provided by firms (dummies) } \\
\hline Training & $\begin{array}{l}-0.020 * * \\
(0.008)\end{array}$ & $\begin{array}{l}0.004 * * \\
(0.002)\end{array}$ & $\ldots$ \\
\hline Kindergartens & $\begin{array}{l}-0.011 \\
(0.007)\end{array}$ & $\begin{array}{l}-0.001 \\
(0.002)\end{array}$ & $\ldots$ \\
\hline $\begin{array}{l}\text { Housing purchase and } \\
\text { construction }\end{array}$ & $\begin{array}{l}-0.009 \\
(0.006)\end{array}$ & $\begin{array}{l}0.003 \\
(0.002)\end{array}$ & $\ldots$ \\
\hline Training costs (days) /100 & $\begin{array}{l}-0.009 * * * \\
(0.003)\end{array}$ & $\begin{array}{l}0.002^{* * *} \\
(0.001)\end{array}$ & $\ldots$ \\
\hline \multicolumn{4}{|c|}{ Type of location (Moscow and St. Petersburg are omitted) } \\
\hline Regional Capital City & $\begin{array}{c}0.014 \\
(0.011)\end{array}$ & $\begin{array}{c}0.009 \\
(0.005)\end{array}$ & $\begin{array}{c}0.0001 \\
(0.0008)\end{array}$ \\
\hline Other city & $\begin{array}{l}0.026 * * \\
(0.011)\end{array}$ & $\begin{array}{c}0.004 \\
(0.005)\end{array}$ & $\begin{array}{l}-0.0021^{* *} \\
(0.0010)\end{array}$ \\
\hline Non-city & $\begin{array}{l}-0.028^{*} \\
(0.016)\end{array}$ & $\begin{array}{l}-0.004 \\
(0.004)\end{array}$ & $\begin{array}{l}-0.0016^{*} \\
(0.0008)\end{array}$ \\
\hline \multicolumn{4}{|l|}{ Legal Environment } \\
\hline $\begin{array}{l}\text { Fraction of cases when managers } \\
\text { failed to pay assessed fines on time }\end{array}$ & $\ldots$ & $\ldots$ & $\begin{array}{l}-0.0091^{* *} \\
(0.0042)\end{array}$ \\
\hline $\begin{array}{l}\text { Fraction of cases when arrears were } \\
\text { paid off after violation was discovered }\end{array}$ & $\ldots$ & $\ldots$ & $\begin{array}{l}-0.0057^{* *} \\
(0.0026)\end{array}$ \\
\hline Observations & 2611 & 4061 & 3984 \\
\hline$R^{2}$ & 0.137 & 0.241 & 0.303 \\
\hline
\end{tabular}

Notes: Sample consists of industrial and agricultural firms. Robust standard errors in parentheses; * significant at $10 \%$; ** significant at $5 \%$; *** significant at $1 \%$. Intercept and dummies for years, industries, and non-reported training costs are included but not shown here. 
Table 7: Non-Linear Reaction Function of Wage Arrears, Nonpublic Sector

\begin{tabular}{lcccc}
\hline & OLS & District FE & Firm FE & $\begin{array}{c}\text { Firm- } \\
\text { Worker FE }\end{array}$ \\
\hline & \multicolumn{3}{c}{ Panel $A$} \\
$\Omega_{j t}$ (local arrears) & -0.097 & $-0.641^{* *}$ & 0.052 & 0.084 \\
$\Omega_{j t}{ }^{2}$ & $(0.230)$ & $(0.288)$ & $(0.269)$ & $(0.306)$ \\
$\Omega_{j t}{ }^{3}$ & $0.234^{* * *}$ & $0.249^{* * *}$ & $0.181^{* * *}$ & $0.175^{* *}$ \\
& $(0.062)$ & $(0.058)$ & $(0.056)$ & $(0.080)$ \\
\hline$R^{2}\left(R^{2}\right.$-within) & $-0.016^{* * *}$ & $-0.015^{* * *}$ & $-0.012^{* * *}$ & $-0.011^{* *}$ \\
& $(0.004)$ & $(0.003)$ & $(0.003)$ & $(0.005)$ \\
$\Omega_{j t}$ (local arrears) & 0.262 & 0.155 & 0.129 & 0.155 \\
$\Omega_{j t}{ }^{2}$ & & Panel $B$ & & \\
$\Omega_{j t}{ }^{3}$ & -0.265 & $-1.023^{* * *}$ & -0.303 & 0.078 \\
& $(0.215)$ & $(0.326)$ & $(0.283)$ & $(0.229)$ \\
\hline$R^{2}\left(R^{2}\right.$-within) & $0.251^{* * *}$ & $0.287^{* * *}$ & $0.215^{* * *}$ & $0.176^{* * *}$ \\
\hline
\end{tabular}

Notes: Observations=12850 employee-respondents in the nonpublic sector. Robust standard errors in parentheses are adjusted for clustering within local areas; * significant at $10 \%$; ** significant at 5\%; *** significant at $1 \%$. The equations in this table also include all other variables in Table 4, but the results for these variables are very similar and therefore not shown here. The specification in Panel B also has a full set of interactions between federal district dummies and year dummies. 


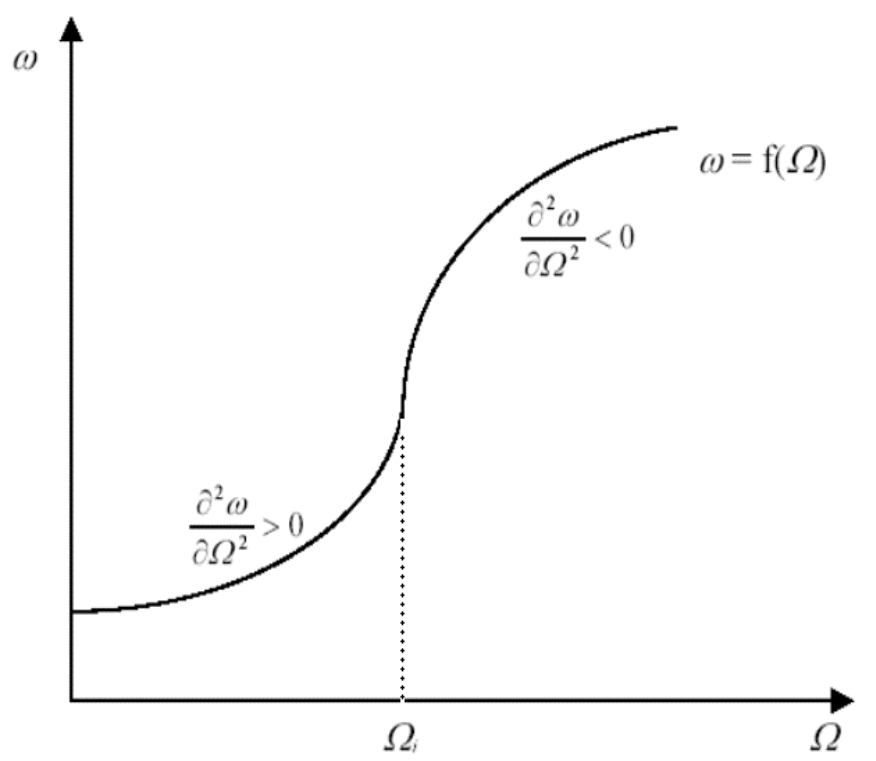

Figure 1: Nonlinear Reaction Function of Wage Arrears

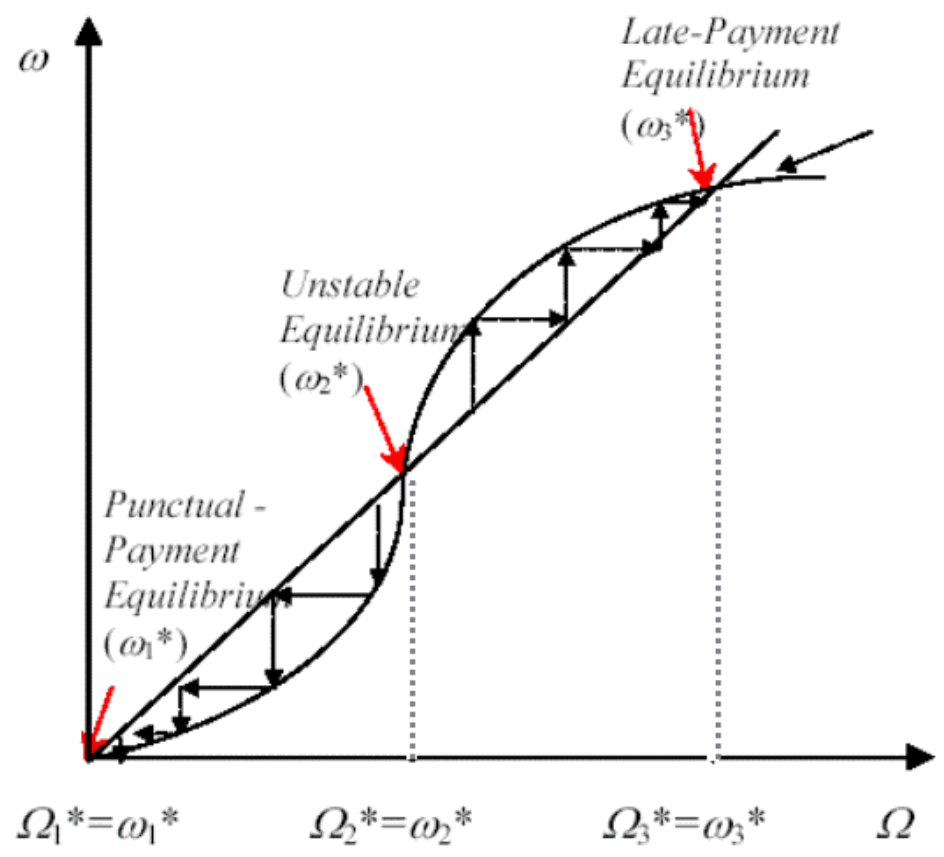

Figure 2: Symmetric Nash Equilibria 


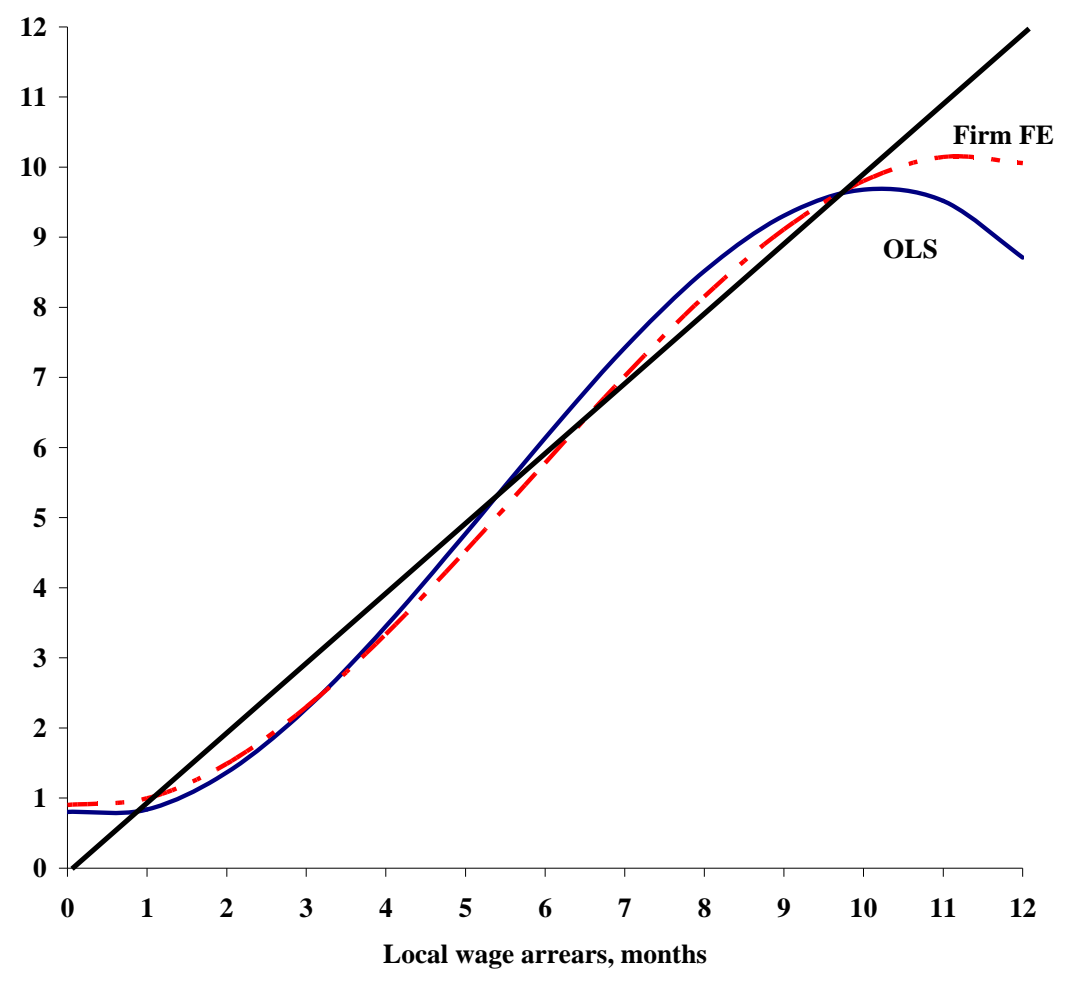

Figure 3: Estimated Nonlinear Reaction Function 